\title{
Phylogeny and Historical Biogeography of Geraniaceae in Relation to Climate Changes and Pollination Ecology
}

\author{
Omar Fiz, Pablo Vargas, Marisa Alarcón, Carlos Aedo, José Luis García, and Juan José Aldasoro ${ }^{1}$ \\ Real Jardín Botanico de Madrid, CSIC, Plaza de Murillo 2, 28014 Madrid, Spain \\ ${ }^{1}$ Author for correspondence (aldasoro@ma-rjb.csic.es)
}

Communicating Editor: Mark P. Simmons

\begin{abstract}
Chloroplast ( $t r n L-F$ and $r b c L$ ) sequences were used to reconstruct the phylogeny of Geraniaceae and Hypseocharitaceae According to these data Hypseocharitaceae and Geraniaceae are monophyletic. Pelargonium and Monsonia are sisters to the largest clade of Geraniaceae, formed by Geranium, Erodium and California. According to molecular dating and dispersal-vicariance analysis, the split of the stem branches of Geraniaceae probably occurred during the Oligocene, in southern Africa or in southern Africa plus the Mediterranean area. However, their diversification occurred during the Miocene, coinciding with the beginning of major aridification events in their distribution areas. An ancestor of the largest clade of Geraniaceae (Geranium, Erodium, and California) colonised a number of habitats in the northern hemisphere and in South American mountain ranges. In summary, the evolution of the Geraniaceae is marked by the dispersal of ancestors from Southern Africa to cold, temperate and often disturbed habitats in the rest of world, where only generalist pollination and facultative autogamy could ensure sufficient seed production and survival.
\end{abstract}

Keywords—autocompatibility, dispersal-vicariance, drought-tolerance, molecular dating, nectaries, $\mathrm{P} / \mathrm{O}$ indexes.

The Geraniaceae are included in the order Geraniales along with the families Francoaceae, Greyiaceae, Ledocarpaceae, Melianthaceae and Vivianiaceae (Soltis et al. 2000; APG II 2003). A number of molecular and morphological studies have included the monogeneric family Hypseocharitaceae within the family Geraniaceae (Boesewinkel 1988; Rama Devi 1991; Price and Palmer 1993; APG II 2003) but they are separated by some morphological features such as fruit and carpel structure (Hutchinson 1969; Slanis and Grau 2001).

Phylogenetic relationships were examined in four genera: Geranium (Price and Palmer 1993; Pax et al. 1997), Pelargonium (Bakker et al. 1998, 1999, 2000, 2004, 2005), Erodium (Fiz et al. 2006), and Monsonia (Touloumenidou et al. 2007). The phylogenetic study of Geraniaceae using $r b c L$ sequences by Price and Palmer (1993) showed Sarcocaulon to be included in Monsonia (Albers 1996a, 1996b; Albers and Löbbert 1996), and Pelargonium to be sister to the other four genera of Geraniaceae. The inclusion of Sarcocaulon in Monsonia was also supported by data on ITS and trnL-F (Touloumenidou et al. 2007). According to Price and Palmer (1993), Erodium and Geranium are phylogenetically close, and California could be a sister group of the subclade formed by Erodium and Geranium (Aldasoro et al. 2002; Fiz et al. 2006).

Geraniaceae have a worldwide distribution but are best represented in Southern Africa. Pelargonium has about 270 species centered in the Cape Floristic Region, Succulent Karoo, Nama Karoo, and KwaZulu-Natal while a lower number of species are found in east Africa, Australia, Madagascar, St. Helena, and Tristan da Cunha (Bakker et al. 1998, 1999, 2005). The 39 species of Monsonia inhabit Africa and southwestern Asia (Kers 1968; Moffett 1979; Venter 1979, 1983; Albers 1996a, b). Erodium has 74 species and shows its greatest diversity in the Mediterranean area (Guittonneau 1972; ElOqlah, 1989; Aldasoro et al. 2000), while California only inhabits western North America (Aldasoro et al. 2002). Geranium is the largest of the family, comprising about 420 species distributed all over the world (Fig. 1; Yeo 1973; Aedo et al. 1998, 2002).

Price and Palmer (1993) proposed that Hypseocharis could be the sister taxon to Geraniaceae. Hypseocharis grows in subalpine habitats of the central Andes (Boesewinkel 1988, 1997; Slanis and Grau 2001). Many members of Geraniaceae are characteristic of the Afro-Arabian land mass (Hutchinson 1969). The differentiation of these genera can be associated with adaptation to desert and steppe environments, which became progressively more extended in Africa and Arabia during the end of the Tertiary (Kers 1968; Venter 1983). The other members of the family are characteristic of today's northern temperate continents, and occupy more mesic environments (Yeo 1984, 1990; Boesewinkel 1988).

Monsonia, Geranium, Erodium, and California bear actinomorphic flowers while Pelargonium flowers are generally zygomorphic. Geraniaceae flowers have one or five nectaries of four types: 1) one nectary formed by a tube in the hypanthium (most species of Pelargonium); 2) five nectaries forming tubes in the hypanthium (two species of Monsonia); 3) five nectaries at the base of the stamens, forming closed nectar pockets due to sepal enlargement (five species of Monsonia), and 4) five external, knob-like nectaries, located at the base of stamens (the remaining species of Monsonia, and all Geranium, California and Erodium) (Vogel 1954, 1998; Link 1990; Aldasoro et al. 2000, 2001, 2002; Touloumenidou et al. 2007). While the nectaries of types 1-3 store the nectar in a concealed tube or bag-shaped structure only accessible to longtongued pollinators, the external knob (4) of the remaining species of Monsonia, Geranium, California, and Erodium is easily accessible to short-tongued insects.

The main pollinators and other reproductive features of the Geraniaceae are known for Pelargonium (Struck and Van der Walt 1996; Manning and Goldblatt 1997; Struck 1997) and Geranium (Green 1978; Mulcahy 1983; Philipp 1985; Hessing 1989; Dlusskii et al. 2000; Kandori 2002). Bakker et al. (2005) published an analysis of the evolution of Pelargonium, studying the possible relationships between pollination types and flower shape. One of the most characteristic pollination syndromes in South Africa is by long-proboscid flies visiting flowers with deep nectaries and is relatively frequent in $\mathrm{Pe}^{-}$ largonium (Goldblatt et al. 1995; Goldblatt and Manning 2006). Other Pelargonium syndromes are by short-proboscid flies, bees, butterflies and birds. Pollinators are less well known for Erodium (Simon et al. 2000) and Monsonia. Thus, further information is necessary to complete the knowledge about the flower-visitor relationships in Geraniaceae. 


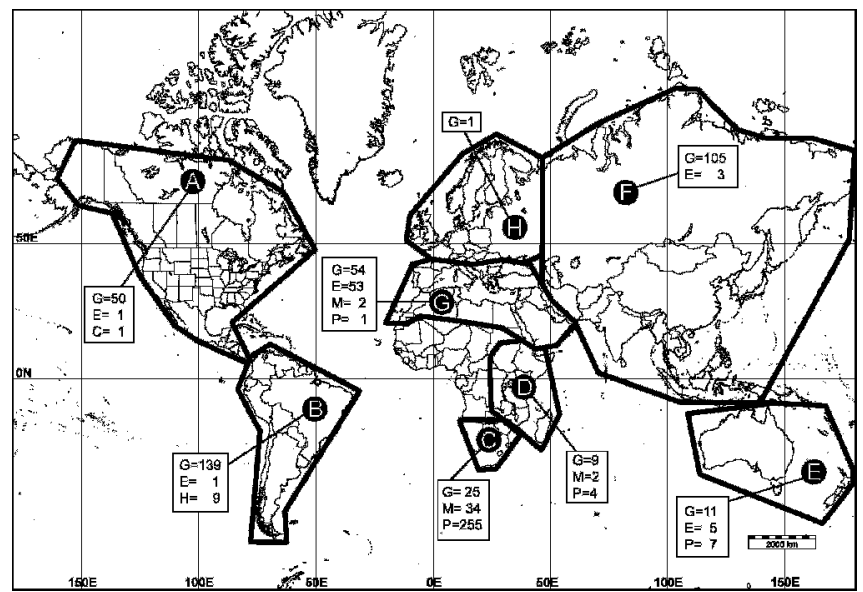

FIG. 1. Distribution map of Geraniaceae and Hypseocharitaceae in the areas used for DIVA analysis. The insets show the number of endemic species for each genus in each area. Genera: C: California, E: Erodium, G: Geranium, H: Hypseocharis, M: Monsonia, P: Pelargonium. Areas: A: North and Central America; B: South America; C: Southern Africa; D: eastern Africa and Madagascar; E: Australia, Tasmania and New Zealand; F: eastern Asia, Indochina, Indonesia and Pacific Islands; G: Mediterranean region, Arabia and Anatolia; H: Europe.

The aim of the present work was to undertake phylogenetic reconstructions of Geraniaceae and examine the ways in which the current geographic distributions came about. Compilation of data about habitats, reproductive and dispersive systems and chromosome numbers would serve to analyse the role of these features in relation to main evolutionary and biogeographic events.

\section{Materials AND MetHODS}

Plant Material and Analyses of Reproductive Features-The plant material used for DNA extractions included fresh and herbarium specimens (Appendix 1). For morphological, reproductive and pollen studies, living and herbarium specimens were examined (Appendix 2). Living specimens were obtained from seeds collected in the field, obtained from botanical gardens, or in two cases bought. Vouchers are housed at Real Jardin Botanico de Madrid (MA)

To obtain information on breeding systems, pollen-ovule $(\mathrm{P} / \mathrm{O})$ indexes were calculated for many species (Appendix 2). Geraniaceae flowers have five fertile ovules, one in each carpel. Thus, for calculating $\mathrm{P} / \mathrm{O}$ indexes, the number of pollen grains per anther was counted, multiplied by the number of anthers per flower and divided by five. Buds were collected, fixed and preserved in "Kew liquid" (Fordman and Bridson, 1989). Anthers were opened under a dissecting microscope and all pollen grains were counted at $3 \times$ magnification. Two anthers from each of five flowers taken from different plants were examined for each species. For dioecious species, the mean pollen grain number of a least ten male flowers was divided by five (the number of fertile ovules per female flower). These results, plus field observations and data from the literature, were used to define the reproductive system of each species (Cruden 1977). Plants grown in the Madrid Botanical Garden (see Appendix 2) were used to test for automatic self-pollination. Twenty inflorescences belonging to three or four plants were bagged before opening, and the number of seeds produced in the mature mericarps counted. A similar number of unbagged plants were tested for free pollination.

Most data about flower visitors were compiled from literature; the rest were obtained by observation in the field (Appendix 3). Absolute number of visits per time, and the number of taxa of pollinators were recorded in a table. Species of Geranium and Erodium were usually censused three times (May, August, and September, 2004-2006, total time of censuses specified in Appendix 3). Due to the difficulty of visiting Monsonia habitats, they were censused only one time, but in two or three locations (December-January, 2005; Appendix 3). Insects were collected, identified and measured in the laboratory.

PCR Amplification, Sequencing, and Sequence Analyses-One hundred and thirty one DNA sequences were included in the analysis, of which $44 \mathrm{trnL}-F$ and $21 \mathrm{rbcL}$ sequences were obtained during this project
(Table 1). Two California macrophylla sequences plus 40 Erodium, 48 Geranium, two Hypseocharis, 16 Monsonia, 12 Pelargonium and 11 outgroups were included. Eighty-five taxa were included in the phylogenetic analyses of trnL-F (Table 1; Appendix 1; Fig. 1), two of which were outgroups (Francoa and Crossosoma). Analysis of $r b c L$ sequences was performed using 46 taxa (Table 1), seven of which were outgroups (Bersama, Crossosoma, Francoa Greyia, Melianthus, Viviania, and Wendtia).

Approximately $20 \mathrm{mg}$ of leaf tissue from fresh (field collected) or herbarium material were taken and the DNA extracted using the DNeasy Plant Mini Kit (QIAGEN Laboratories, Hilden, Germany). The forward primer ' $\mathrm{e}$ ' and reverse primer ' $\mathrm{f}$ ' were used for PCR amplification of the trnL(UAA)-trnF(GAA) spacer (Taberlet et al. 1991), and primers 1F, 636F, 724R and 1460R for $r b c L$ sequences (Olmstead et al. 1992; Fay et al. 1998). The PCR conditions for the amplification of $t r n L-F$ and $r b c L$ are described in Fiz et al. (2006) and Savolainen et al. (2000a), respectively. The amplified products were purified using spin filter columns (PCR Clean-up kit, MoBio Laboratories, Carsbad, California). Cleaned products were sequenced according to Fiz et al. (2002).

Sequence data were stored in a contig file and edited using the Seqed program (Applied Biosystems, Branchburg, New Jersey). Pairwise divergence among sequences was calculated by using the NJ method (Saitou and Nei 1987) with the Kimura 2-parameter distance model (Kimura 1980).

The $t r n L-F$ sequences had $217-413 \mathrm{bp}$ depending on taxa. The largest divergences in sequence between taxa reached $27.94 \%$ in Geraniaceae and $45.89 \%$ in Geraniales. For rbcL sequences, differences reached $11.05 \%$ in Geraniaceae and $18.22 \%$ in Geraniales.

Clustal X ver. 1.62b (Thompson et al. 1997) was used for the alignment of the sequences, followed by manual adjustment to maximize similarity (Simmons, 2004). Balbisia and Wendtia showed no identical fragments in the $\operatorname{trn} L-F$ matrix and it was not possible to align them; consequently they were not used in this analysis. Cladistic analyses were conducted using Fitch parsimony (Fitch 1971) with unordered, equally weighted characters. Heuristic searches were performed using ACCTRAN optimisation.

Phylogenetic reconstructions of the $r b c L, t r n L-F$ and combined matrices were carried out using PAUP* 4.0b10 (Swofford 2002) and MrBayes ver. 3.0b4 (Ronquist and Huelsenbeck 2003). A heuristic search was performed with 100 replicates of random addition sequences, Tree BisectionReconnection (TBR) branch swapping, and with the Mulpars option selected. Bootstrap analyses (Felsenstein 1985) were performed using 1000 replicates, random taxon addition with 10 replicates per replicate and no branch swapping. For simultaneous analysis (Kluge, 1989; Nixon and Carpenter 1996) we combined the $t r n L-F$ and $r b c L$ datasets, using missing value marks for the parts not sequenced. Since the $\operatorname{trn} L-F$ and combined matrices are very large, data analyses aborted in the first replicate. Thus, we analyzed them using PRAP/PAUP (Müller 2003, 2005), which allows running the parsimony ratchet (Nixon 1999). Trees and data matrices for $r b c L$ and $t r n L-F$ are posted at TreeBASE (study number S1569).

To determine the simplest model of sequence evolution that best fit the data, the hierarchical likelihood ratio test (hLRT, Felsenstein 1988) and the Akaike information criterion (AIC, Akaike 1974) were used employing MrModeltest 1.1b software (Nylander 2002). Both tests selected the same substitution models: GTR $+\Gamma$ for the $\operatorname{trn} L-F$ matrix, and GTR $+\Gamma+$ I for $r b c L$. The proportion of variable sites for $t r n L-F$ was $50 \%$ in Geraniales (44\% in Geraniaceae subset), from which informative ones was 33\% (30\% in Geraniaceae). For $r b c L$, the proportion of variable sites was $26 \%$ in Geraniales (19\% in Geraniaceae), and the informative ones 18\% (13 in Geraniaceae subset)

A Bayesian MCMC analysis (Yang and Rannala 1997) using MrBayes ver. 3.0b4 (Huelsenbeck and Ronquist, 2001) was run for 2 million generations using the default parameters. A 50\% majority rule tree was obtained after discarding the first $10^{4}$ ( $r b c L$ matrix) or $10^{5}(\operatorname{trn} L-F)$ generations as burn-in prior to reaching stationarity. MacClade ver. 3.08 (Maddison and Maddison 1992) was used to map the distribution of character state changes.

Biogeographical Analyses and Molecular Datations-Ancestral areas were reconstructed for both $t r n L-F$ and $r b c L$ using dispersal-vicariance analysis (DIVA; Ronquist 1997). Areas of endemism were defined by the presence of at least one endemic taxon (Fig. 1). The program demands fully resolved trees; the tree with the highest likelihood obtained from the Bayesian analysis was selected for this purpose.

Two relaxed-clock methods using different statistical bases were used to reconstruct divergence times for each marker: the Penalized Likelihood approach (PL) (Sanderson 2002) and the Bayesian Relaxed Clock (BRC) (Kishino et al. 2001; Thorne et al. 1998, 2002). These reconstructions were performed by r8s ver. 1.70 (http://ginger.ucdavis.edu/r8s/; Sanderson 2002) and Multidivtime (ver. 09.25.03, Thorne and Kishino 2002). A 50\% 
majority rule consensus tree (obtained from the BI tree) was used for reconstructing the divergence times of each node for each marker. The clock hypothesis was rejected using the likelihood ratio test.

Calibration points were obtained from fossils and published dating analyses. An upper age constraint was deduced from the data of Wikström et al. (2001, appendices: node 183), who calculated the age of many clades of the angiosperm tree by calibrating it with a fossil of the Fagales. The ages obtained by these authors ranged between 47 and 38 MYA for the ancestral node of Geraniaceae excluding Hypseocharitaceae (node D in Figs. 2, 3, but see also Bakker et al. 2005). Thus, we used these data as minimum and maximum constraints for node D. Minimum age constraints for two terminal subclades were taken from the fossil record

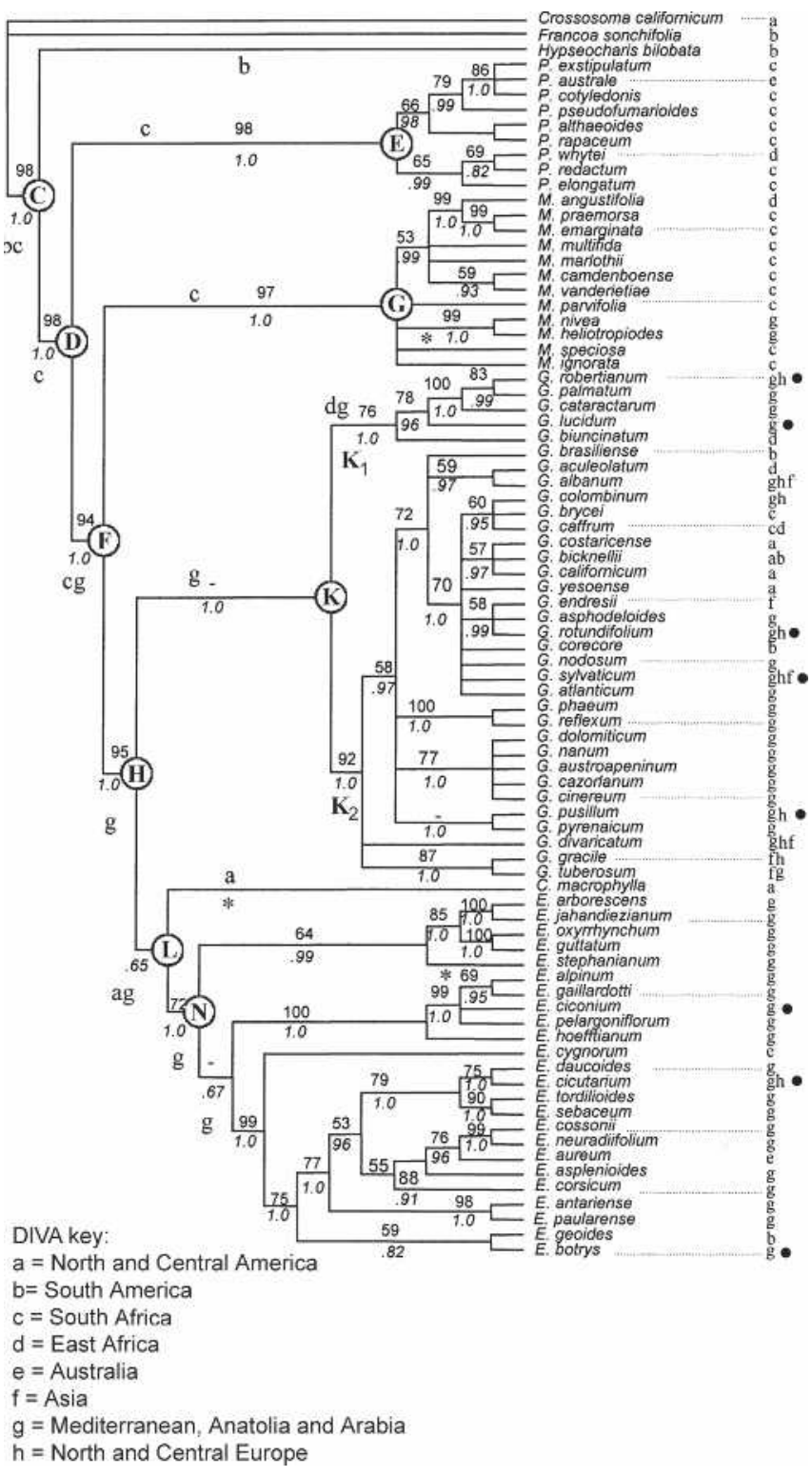

FIG. 2. Strict consensus of the 1,962 most parsimonious trees obtained in $\operatorname{trn} L-F$ analysis. Numbers above branches are bootstrap values; those below are posterior probabilities. Branches in the parsimony tree that contradicted Bayesian tree are indicated by * under the branch. The number of steps was 683, CI $=0.637$ (excluding parsimony-uninformative characters), $\mathrm{RI}=0.884$. Circled letters are node names; non-circled letters are ancestral areas inferred from DIVA analysis (see Fig. 1 for area interpretation). The letters on the right represent the distribution of each taxon analysed (see Fig. 1 for area interpretation). As the topologies are different, the nodes are marked differently in Fig. 2 with respect to Figs. 3 and 4 . The geographic distribution of species marked with $\bullet$ is tentative, because they were probably dispersed by the man to different continents. 


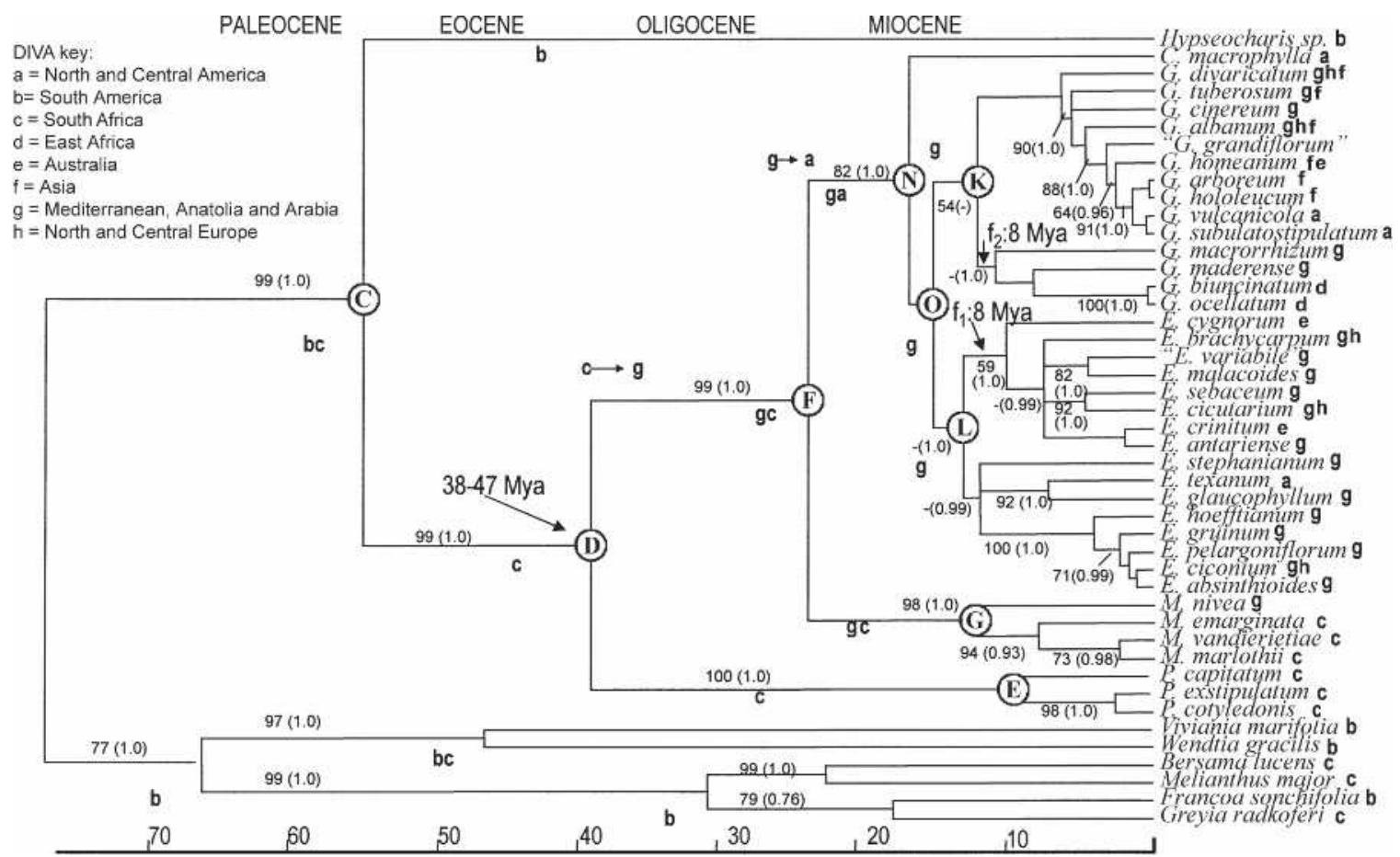

FIG. 3. Chronogram reconstructed after analysing $r b c \mathrm{~L}$ with $\mathrm{r} 8 \mathrm{~s}$. It was obtained from a consensus of the 6 MPTs obtained in $r b c \mathrm{~L}$ analysis. Numbers beside branches that are not in parentheses are bootstrap values; those in parentheses are posterior probabilities. The number of steps was $776, \mathrm{CI}=0.517$ (excluding parsimony-uninformative characters), and $\mathrm{RI}=0.783$. Circled letters are node names; non-circled letters are ancestral areas inferred from DIVA analysis. The pairs of letters linked by arrows indicate inferred dispersal events. Node D was constrained for minimum and maximum dates of 47 and 38 MYA. The dates linked by arrows to nodes are minimum age constraints of 8 MYA for two terminal points (arrows $\mathrm{f}_{1}$ and $\mathrm{f}_{2}$ ).

(arrows $\mathrm{f}_{1}$ and $\mathrm{f}_{2}$ in Fig. 3). The only available Geraniaceae fossils confidently assignable to Geraniaceae are pollen grains from the middle Miocene of Spain (Van Campo 1989). Photographs of these grains were examined by the authors and two of them were assigned to Erodium subg. Barbata (pollen with interwoven striae; the rest of subgenera is reticulate), and Geranium subg. Robertium (pollen with sexine 2 distinct, nearly reticulate; in the rest of Geranium groups the sexine is indistinct, and is covered by supratectal elements; see Stafford and Blackmore 1991).

To estimate the divergence times of the Geraniaceae nodes, the r8s penalized likelihood method (PL) was used (Sanderson 2002). Searches were started at five different time estimates. Each estimate was perturbed and restarted up to three times to avoid local stability. The smoothing parameter $\left(\log _{10} \lambda\right)$ was calculated by cross-validation. The lowest cross validation score was found by testing different smoothing values $(\lambda=$ $10 x)$, starting at 1 and increasing the value of $x$ by steps of 0.5 up to 1,012 . The smoothing value of and $\lambda=32(r b c L)$ and $\lambda=10(\operatorname{trnL}-F)$ corresponded to the lowest prediction error (the lowest cross validation score); it therefore provided the best semiparametric model for the data (Sanderson 2002).

Multidivtime was used following the procedure outlined by Rutschmann (2004), which involves the use of three programs: Baseml (PAML ver. 3.14; Yang 1997), Estbranches (ver. 8-5-03; Thorne et al. 1998) and Multidivtime (ver. 9-25-03; Kishino et al. 2001; Thorne and Kishino 2002). After the parameters were estimated from the data using Baseml, branch-lengths (and variances and covariances) were estimated using Estbranches. Finally, Multidivtime served to estimate the posterior distributions, substitution rates and node times using a Bayesian procedure. The settings used in Multidivtime were: for the age of the root (rttm prior) and its standard deviation, we used a value of 1.5 , which equals 45 MYA $(1.5 \times 30)$; for the prior on rate change (brownmean). For its standard deviation we selected a value of 0.4 obtained form estbranches data. Bigtime value was set at 100 MYA, other values were default values of the package Multidivtime.

Rates of diversification were obtained using equation 7 of Magallón and Sanderson (2001). Estimators of rate of diversification were calculated, assuming that the rate of relative extinction $\in$ varied between a lower and upper limit of 0 and 0.9 (Magallón and Sanderson 2001).

\section{RESULTS}

Analysis of trnL-F, rbcL and Combined Matrices-Figures 2 and 3 show the results obtained from the $t r n L-F$ and $r b c L$ sequences, respectively. Parsimony and Bayesian analysis produced similar topologies, with high support for the clade formed by Geraniaceae plus Hypseocharitaceae (node C) and for that of Geraniaceae alone (node D, Fig. 2). However, the $r b c L$ tree indicates low support for the remaining Geraniales as sister to Geraniaceae plus Hypseocharitaceae. The combined matrix produced a topology similar to that of the independent data sets but differing in its branch support (Fig. 4).

The $\operatorname{trn} L-F$ and $r b c L$ trees showed four main nested clades: 1) Hypseocharis as sister to Geraniaceae (node C), 2) Pelargonium as sister to all the remaining Geraniaceae (node D), 3) Monsonia, including the section Sarcocaulon (node G), and 4) a large clade comprising Geranium, Erodium, and California (node $\mathrm{H}$ for $\operatorname{trn} L-F$ and node $\mathrm{N}$ for $r b c L$ ). The fourth clade showed different topologies depending on the locus used. The clade of Monsonia was unresolved with respect to trnL-F; showing two nested polytomies. The phylogenetic relationships between Geranium, Erodium, and California are unclear because of the low support for the alternative topologies inferred from both markers (Figs. 2, 3).

The clade of the genus Geranium showed two main branches, one formed by most species of subg. Robertium $\left(\mathrm{K}_{1}\right.$, Fig. 2$)$, and the other formed by the remaining subgenera $\left(K_{2}\right.$, Fig. 2). This is consistent across all analyses. Two main branches appeared in the trnL-F and rbcL analysis of Erodium, and the monophyly of this genus is well supported in Bayesian analyses (Figs. 2-4). 


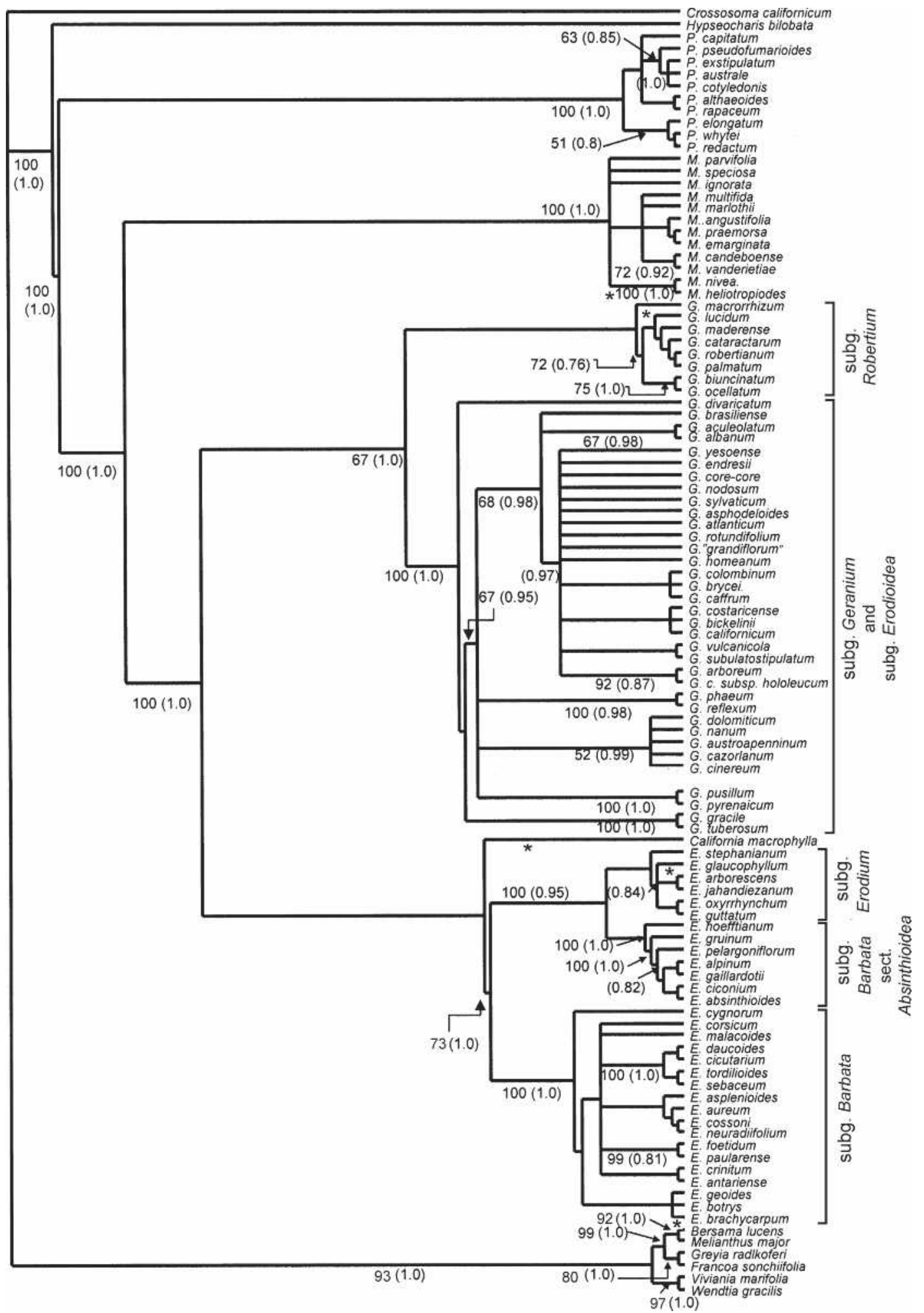

FIG. 4. Strict consensus of the 400 most parsimonious trees obtained from combined $r b c L$ and $t r n L-F$. Numbers beside branches that are not in parentheses are bootstrap values; those in parentheses are posterior probabilities. Branches in the parsimony tree which contradicted Bayesian tree are indicated by * under the branch. The number of steps was 1,439, CI = 0.656 (excluding parsimony-uninformative characters), and RI $=0.841$. Guittonneau's (1990) classification of Erodium and Yeo's (1990) classification of Geranium are indicated on the right side of the tree.

The topologies obtained by parsimony and BI analyses were quite similar for both the trnL-F and $r b c L$ matrices (Figs. $2,3)$. In the simultaneous analysis, only the positions of California macrophylla, Erodium brachycarpum, E. glaucophyllum, Geranium macrorrhizum, and the branch of Monsonia nivea-M. heliotropioides are in conflict (Fig. 4). If $t r n L-F$ and $r b c L$ trees are compared, only the position of California macrophylla is in conflict. In the trnL $-F$ tree, California is sister to Erodium, while in $r b c L$ it is sister to the clade formed by Erodium and Geranium; neither topology had strong bootstrap support. 
Biogeographical Analyses-The biogeographic analysis using DIVA resulted in a single optimal reconstruction requiring 14 dispersals for the trnL-F tree and 11 for the $r b c L$ tree (Figs. 2, 3 respectively, see letters over the nodes). South America plus Southern Africa (area bc) was suggested as the ancestral area for Geraniaceae plus Hypseocharitaceae (node C).

The clade of the ancestor of crown node of Geraniaceae (node D) was assigned to Southern Africa (area c). The nested clade formed by the ancestor of Monsonia, Geranium, Erodium, and California was assigned to the composite Southern Africa plus Mediterranean-West Asian region in the $\operatorname{trn} L-F$ tree (area cg, node F), while that of Pelargonium was assigned to Southern Africa (c). Thus, a dispersal event towards the Mediterranean-West Asian region was required for an ancestor of Monsonia, Geranium, Erodium, and California.

Many of the upper nodes of Geranium were unresolved and assigned to large combinations of areas, probably due to dispersal events. Conversely, the lower nodes of Erodium were assigned to the Mediterranean-West Asian region, except for one which was assigned to area eg (Mediterranean plus Australia), which is explained by a long-distance dispersal event.

Reconstruction of Divergence Times-Upper and lower constraints for the split of the genus Pelargonium were obtained from the data of Wikström et al. (2001), while two Geraniaceae fossils were used to constrain the terminal branches. These data yielded a rate of $8.64 * 10^{-10}$ substitutions per site per year (s/s/y) for $r b c L$, and $2.2610^{-9} \mathrm{~s} / \mathrm{s} / \mathrm{y}$ for trnL-F. Results are shown in Table 1 and the chronogram of Fig. 3.

Node F marks the separation of the ancestor of Geranium, Erodium, and California and the ancestor of Monsonia (Fig. 3; Table 1). The data obtained for these nodes indicate the late Oligocene as the time of splitting between these branches (26-34 MYA), which should be distributed in Africa, the Mediterranean, and West Asian region. According to our results, the age of separation of the clade formed by Geranium, Erodium, and California (nodes $\mathrm{N}$ or $\mathrm{H}$ ) is between 18-29 MYA. These ages range from the late Oligocene to the lower Miocene. The diversification of Monsonia, Geranium, and Erodium seems to have occurred from the mid-Miocene onwards. Also, the diversification of the largest clade of Geranium seems to be recent, during the later Miocene (G. subg. Geranium sensu lato, grouping more than 380 species)

Table 2 shows the diversification rates for the family Geraniaceae. Pelargonium (0.28-0.42) and Geranium (0.25-0.37) show high rates in contrast to Erodium and Monsonia which showed the lowest rates $(0.1-0.23)$.

P/O Indexes and Pollination in Geraniaceae-Most species of Pelargonium are distributed in Africa (Fig. 1), and have medium to low $\mathrm{P} / \mathrm{O}$ indices (Fig. 5). They are generally au-

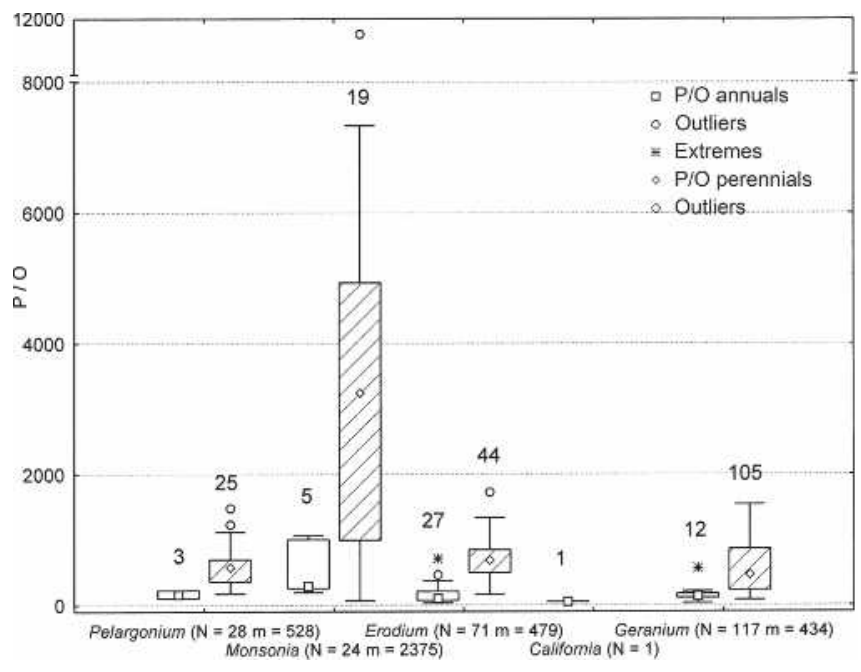

FIG. 5. Box-plots of $\mathrm{P} / \mathrm{O}$ indexes in annuals and perennials of genera of Geraniaceae. Numbers over the box-plots are the number of species studied. Numbers under the genera are total numbers of species studied per genus and the $\mathrm{P} / \mathrm{O}$ medians obtained. They are taken from bibliographic and field data compiled in Appendix 2.

toincompatible and visited by a low number of visitors, mainly medium to long-tongued Diptera, Lepidoptera, and large bees (Table 3, Appendix 3). Pollination by birds, shorttongued Diptera, wasps, and auto-pollination are comparatively rare in this genus.

Monsonia species with nectar-pockets have very high $\mathrm{P} / \mathrm{O}$ indexes and are probably pollinated by long-tongued insects, but our observations are limited to M. drudeana (Table 3, Appendix 3, Fig. 5). Two Monsonia species with tubular nectaries that grow in east Africa have low $\mathrm{P} / \mathrm{O}$ indices and their pollinators are unknown. The remaining species of Monsonia have accessible, knob-like nectaries, and are visited by a range of pollinators (Bombylidae, wasps, large bees, Lepidoptera, etc.) and produce a lot of pollen. The $\mathrm{P} / \mathrm{O}$ indexes of 11,753 for $M$. speciosa and 7,337 for M. ciliata are uncommon for Geraniaceae.

Erodium is distributed mainly in the Mediterranean basin where it grows in mountainous and disturbed places. 32.87\% of all Erodium species are autogamic annuals that colonize disturbed habitats (Fig. 1). Erodium showed a large proportion of species with low $\mathrm{P} / \mathrm{Os}$ and they are in many cases selfers (Appendix 2; Fig. 5). In some cases, auto-pollination increases in stressful situations or at the end of the flowering season. The number of visitor taxa per species is quite similar in Erodium and Geranium (Erodium with a median 11 taxa per species, and Geranium with a median 9 taxa per species; Fig. 6), and it is higher than in the rest of genera. Although our observations on visits per time are quite limited, they suggest that visitors are relatively scarce in Monsonia and compar-

TABLE 2. Diversification rates of Geraniaceae using rbcL data and some features related to types of reproduction (一: not studied).

\begin{tabular}{|c|c|c|c|c|c|c|}
\hline Taxa & $\begin{array}{l}\text { B: Hypseocharitaceae } \\
\text { plus Geraniaceae }\end{array}$ & C: Geraniaceae & E: Pelargonium & G: Monsonia & K: Geranium & L: Erodium \\
\hline Total number of species & 810 & 801 & c270 & 39 & c420 & 74 \\
\hline Date proposed for split of the genus (MYA) & 64.32 & 45.8 & 11.47 & 14.52 & 14.96 & 15.46 \\
\hline Diversification rate for extiction rate $\epsilon=0$ & 0.0933 & 0.1308 & 0.4277 & 0.2046 & 0.3698 & 0.2336 \\
\hline Diversification rate for extiction rate $\epsilon=0.9$ & 0.0677 & 0.0948 & 0.2857 & 0.1045 & 0.2564 & 0.1336 \\
\hline $\begin{array}{l}\text { Pergentage of facultative or mostly autogamous species } \\
\text { (considering } \mathrm{P} / \mathrm{O} \text { and automatic selfing) }\end{array}$ & - & 14.9 & 1.9 & 15.3 & c20 & 37 \\
\hline
\end{tabular}



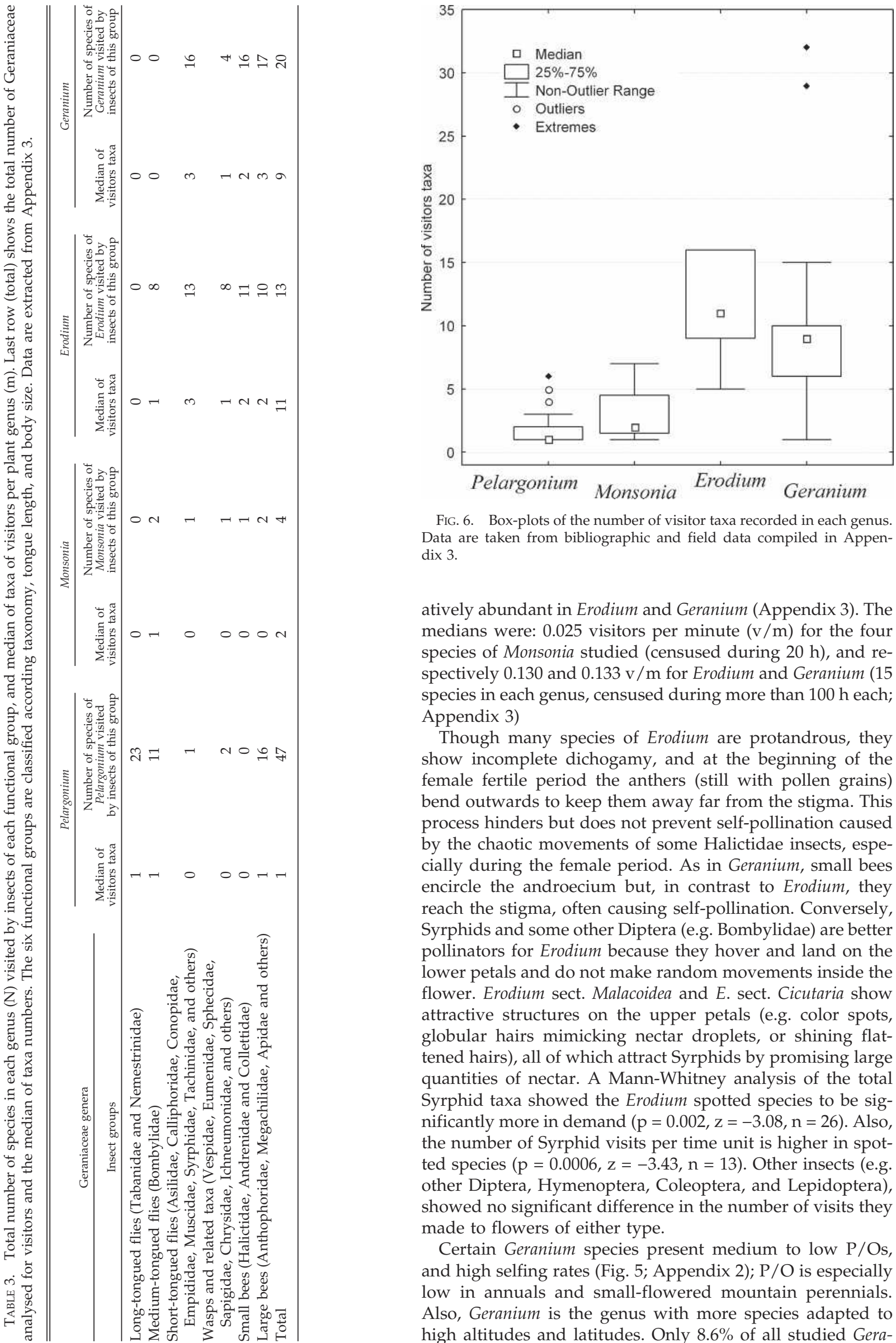

FIG. 6. Box-plots of the number of visitor taxa recorded in each genus. Data are taken from bibliographic and field data compiled in Appen$\operatorname{dix} 3$.

atively abundant in Erodium and Geranium (Appendix 3). The medians were: 0.025 visitors per minute $(\mathrm{v} / \mathrm{m})$ for the four species of Monsonia studied (censused during $20 \mathrm{~h}$ ), and respectively 0.130 and 0.133 v/m for Erodium and Geranium (15 species in each genus, censused during more than $100 \mathrm{~h}$ each; Appendix 3)

Though many species of Erodium are protandrous, they show incomplete dichogamy, and at the beginning of the female fertile period the anthers (still with pollen grains) bend outwards to keep them away far from the stigma. This process hinders but does not prevent self-pollination caused by the chaotic movements of some Halictidae insects, especially during the female period. As in Geranium, small bees encircle the androecium but, in contrast to Erodium, they reach the stigma, often causing self-pollination. Conversely, Syrphids and some other Diptera (e.g. Bombylidae) are better pollinators for Erodium because they hover and land on the lower petals and do not make random movements inside the flower. Erodium sect. Malacoidea and E. sect. Cicutaria show attractive structures on the upper petals (e.g. color spots, globular hairs mimicking nectar droplets, or shining flattened hairs), all of which attract Syrphids by promising large quantities of nectar. A Mann-Whitney analysis of the total Syrphid taxa showed the Erodium spotted species to be significantly more in demand ( $\mathrm{p}=0.002, \mathrm{z}=-3.08, \mathrm{n}=26)$. Also, the number of Syrphid visits per time unit is higher in spotted species ( $\mathrm{p}=0.0006, \mathrm{z}=-3.43, \mathrm{n}=13)$. Other insects (e.g. other Diptera, Hymenoptera, Coleoptera, and Lepidoptera), showed no significant difference in the number of visits they made to flowers of either type.

Certain Geranium species present medium to low P/Os, and high selfing rates (Fig. 5; Appendix 2); $\mathrm{P} / \mathrm{O}$ is especially low in annuals and small-flowered mountain perennials. Also, Geranium is the genus with more species adapted to high altitudes and latitudes. Only $8.6 \%$ of all studied Gera- 
nium $(\mathrm{N}=186)$ are autogamic annuals growing in lowaltitude disturbed habitats. The large flowers of many species of Geranium favor larger visitors. Large bees and bumblebees are the most effective pollinators in this genus, while small bees and flies have difficulty successfully pollinating this type of flower (Table 3; Appendix 3).

\section{DISCUSSION}

Evolution of the Geraniaceae-The phylogenetic analyses of the trnL-F and $r b c L$ sequences gave consensus trees with only one point of incongruence: the position of California macrophylla. In addition, the main branches were well supported in the simultaneous analysis (Fig. 4). The trees obtained by parsimony and Bayesian analyses were congruent for most clades and confirm the conclusions of Price and Palmer (1993) and the APG II (2003), showing Hypseocharis as the sister group of Geraniaceae s.str. The monophyly of Geraniaceae plus Hypseocharitaceae and the Geraniaceae alone were corroborated. The position of Geraniaceae plus Hypseocharitaceae in the order Geraniales was studied by Soltis et al. (2000), Savolainen et al. (2000a, b), and Wikström et al. (2001), who reported good support for both taxa as monophyletic groups. The position of Hypseocharis in the phylogenetic trees (Figs. 2-4), the degree of molecular divergence, and the morphological differences with its closest relatives, suggest that Hypseocharis is a taxon related to ancestors of Geraniaceae s.str. that survived in subalpine meadows of the central Andes.

The genus Pelargonium was found to be the sister group of the remaining genera of Geraniaceae, which was first reported by Price and Palmer (1993). However, Pelargonium species show a mixture of plesiomorphic and apomorphic traits. Some of these synapomorphies include zygomorphy of the flower, the reduction of five nectaries to one (a tube deep inside the hypanthium), the reduction of the stamens from 15 to $5-8$, and anemochorous mericarps assisted by a pappus. The plesiomorphic characteristics include shape of the mericarps (fusiform), and fruit bristles without rims (Aldasoro et al. 2001).

The present results favor the inclusion of Sarcocaulon in Monsonia, as proposed by Albers (1996a, 1996b) and suggested by phylogenetic analyses based on morphology (Aldasoro et al. 2001) and ITS and trnL-F markers (Touloumenidou et al. 2007). The present analyses confirm the distinctiveness of California, although its phylogenetic position remains unclear. According to the $r b c \mathrm{~L}$ and simultaneous analysis trees, California might be sister group of the clade of Geranium and Erodium.

Finally, the infrageneric groups retained in the present analysis only partly reflected their current taxonomic classification within the genera Geranium and Erodium (Guittonneau 1972; Yeo 1984; El-Oqlah 1989). More extensive sampling is needed to acquire sufficient information for a new taxonomic treatment.

Biogeography and Age Estimates-The biogeographic analyses suggest South America and Southern Africa to be the ancestral home range of the Geraniales (Figs. 1-3). The families of Geraniales show several transAtlantic connections that can be explained by vicariance and/or dispersal.

According to DIVA, separation of the sister genera to the largest Geraniaceae clade occurred in Southern Africa and the Mediterranean. The early split between Pelargonium and the ancestors of Monsonia, Erodium, Geranium, and California could suggest that long-tongued pollinators were already present in Southern Africa during their early split. However, Bakker et al. (2005) reported that the ancestral pollination system of Pelargonium is by short-tongued flies or bees, while pollination by long-tongued flies may be a derived character. In that case, concealed nectaries could also be convergent synapomorphies derived in different clades. According to our reconstruction of Geraniaceae phylogeny, splitting between the deep-nectary and knob-nectary Monsonia is feasible in Southern Africa during the midMiocene, probably driven by changes in the composition of pollinator communities.

Most Pelargonium and Monsonia species are droughttolerant; species of Monsonia sects. Sarcocaulon and Monsonia are the best adapted to deserts and semideserts. Between 75 and 30 MYA, much of Africa was occupied by lowland rainforest very similar to those of present-day west central Africa (Axelrod and Raven 1978). Arid episodes may have occurred in southwestern Africa since the Cretaceous, 80 MYA (Ward et al. 1983) to the early Oligocene, 34 MYA (Van Zinderen Bakker 1975; Dieckmann et al. 2004). However, the most intense aridification seems to have take place in the midMiocene (around 10-15 MYA) after the final establishment of the Benguela current (Siesser 1980). The progressive change towards a drier and colder climate might have triggered the diversification of the two main lines of drought-adapted Geraniaceae: Pelargonium and the fleshy Monsonia. Aridification greatly accelerated in Africa during the late Miocene and Pliocene, largely as a result of the uplift of the continent and the further development of the Rift Valley (Axelrod 1972; Baker et al. 1972). During this age, Pelargonium reached its greatest rate of diversification in Southern Africa (Bakker et al. 2004, 2005).

If the position of the genus California in the $r b c L$ and the simultaneous analysis tree is accepted (Fig. 4), a dispersal event to North America must have occurred for ancestors of California, Erodium, and Geranium. Thus, the ancestors of the largest clade of Geraniaceae may have dispersed from Southern Africa to Eurasia via the Saharo-Sindian deserts and later to North America (Van Zinderen Bakker 1969), or from North Africa to Europe and then to North America (Lavin et al. 2000).

Finally, it is important to comment on the diversification of the largest clade of Geraniaceae, with more than 400 species of Geranium and 74 of Erodium. According to our estimates (Fig. 3), this diversification occurred mainly in the Mediterranean Basin and in Eurasia during the latter part of the Miocene and Pliocene. The appearance of many mountain systems and the climate changes in these regions could have encouraged the ancestors of some current species of Erodium and Geranium to adapt to disturbed or to high and cold environments. Many nodes sister to the central clade of Erodium were assigned to the Mediterranean-west Asian region and just one to the Australia and Mediterranean-west Asian region. This suggests long distance dispersal from the Mediterranean Basin or west Asia to Australia. Also several groups of Geranium seem to have dispersed repeatedly to South America. Successful long-distance dispersal has been described between Australia and the northern hemisphere (Smissen 2003; Fiz et al. 2006).

Some of the characteristics of Geraniaceae mericarps (e.g. plumose awns, pappus, or adhesive devices) seem not to 
relate to the extent of their distribution area, diversification rate, nor chance for long-distance dispersal. However, DIVA analyses indicated that certain Erodium and Geranium might have experienced several dispersal events from the Mediterranean to Australia or America (Fiz et al. 2006). Also several species of Pelargonium sect. Peristera might have dispersed from South Africa to Australia, St Helena, and Tristan da Cunha (Bakker et al. 1998). Some authors compared certain characters and parameters indicative of wind dispersal capability in Geraniaceae, concluding that many species of Pelargonium, Erodium, and Monsonia have measurable winddispersal capabilities (Zeide 1976; Rösch 1977, 1978; Loria and Noi-Meir 1980; Burke et al. 1998). Others have reported that Erodium and Geranium mericarps (or seeds) can be collected, eaten, or transported by ants (myrmecochory), reptiles, birds and mammals (by ectozoochory or endozoochory; Hayward in Ridley 1930; Soholt 1973; Skorupa et al. 1980; Shmida and Ellner 1983; Lane et al. 1999; Albert et al. 2005; El Mouden et al. 2006).

However, Stamp $(1984,1989)$ and Van Reede and Van Rooyen (1999) indicated that the dispersal distance of certain Geraniaceae, such as Erodium, is low. Based on experimental simulations, Stamp $(1984,1989)$ found that mericarps were never dispersed by more than $3 \mathrm{~m}$. Clark (1998) and Higgins and Richardson (1999) have used mathematical simulations to explore potential spread rates, and reported that relatively infrequent long distance dispersal events can strongly influence the final figure obtained. Thus, dispersal strategies could increase their complexity by these rare events, such as sporadic myrmecochory and ecto- or endo-zoochory, which have been observed in both Erodium and Geranium.

Flower Evolution, Pollination Ecology, and Diversification Rates-The visitor-plant relationship is an important selective force during evolution and can lead to a faster diversification rate. The rates of diversification of Erodium and Monsonia are similar to the average values of other angiosperms (Table 2), but not to those of Geranium and Pelargonium, which are somewhat higher than the mean (Magallón and Sanderson 2001). Struck and Van der Walt (1996) reported that Pelargonium presents a considerable diversity in flower shape and pollination syndromes. Also, Bakker et al. (2005) reported a correlation in certain clades between the number of species and a shift to long-tongued pollination. In Southern Africa, several other specialised pollination systems, involving long-tongued insects, have been reported (Table 3; Johnson and Steiner 2000; Goldblatt and Manning 2006). Various authors have proposed three alternative explanations: the higher incidence of specialized pollinators in the region (Barraclough 2006; Goldblatt and Manning 2006; Van der Niet et al. 2006), a depauperate pollinator fauna (Johnson and Bond 1992; Johnson 1996; Barraclough 2006) or the existence of a pollinator mosaic (Johnson 1996). Also, Ricklefs and Renner (2000) reported the existence of a significant relationship between high species diversity and animal pollination and herbaceousness.

In agreement with their different types of nectaries and distribution, the main groups of Geraniaceae could be subject to different selective pressures depending on their pollination ecology and habitats. Most Pelargonium with deep nectaries and Monsonia with sepal-concealed nectaries are restricted to Southern Africa and Namibia. In contrast, northern species of Monsonia (Saharo-Sindian area), as well as California, Geranium, and Erodium (northern hemisphere and
South American ranges), produce unspecialized flowers that attract many taxa of insects. Those genera presumably faced the climatic deterioration and loss of pollinators at the end of the Tertiary by a shift to generalist pollination and a higher reproductive flexibility.

The Mediterranean flora is distinguished by a high proportion of annual taxa, which is likely to have resulted from long-lasting disturbance regimes (Shmida 1981; Pons and Quezel 1985; Herrera 1991; Fiz et al. 2002). The clade of Erodium, California, and Geranium colonised the Mediterranean, much of Europe and America during the end of Tertiary, once or more times, and must have acquired new sets of pollinators. As opportunistic bees dominated many of these regions, the possibilities for floral specialization were limited (Schemske 1983). Moreover, generalization usually reduces the risk of reciprocal declines between pollinators and plants (Deyrup and Menges 1997).

Geranium includes more species adapted to wide ranges in altitude and latitude than the other genera of Geraniaceae. The diversification rate of this genus is high (only that of Pelargonium is higher in Geraniaceae). The speciation could be triggered, at least in parts of its range, by the formation of new mountain ranges and climatic deterioration. Studies on the insects found over altitude and latitude gradients showed that the tundra is home to many more Diptera than large Hymenoptera (Table 3; Blionis and Vokou 2002; Totland 1993; Elberling and Olesen 1999). However, only large bees and bumble-bees maintain high levels of activity and efficiency under low temperatures (Bingham and Orthner 1998; Bingham and Ranker 2000). Thus, large bees and bumblebees are the best pollinators of Geranium in these habitats (Kandori 2002; Dlusskii et al. 2000).

Erodium, the genus with most species growing in disturbed habitats (and many of them with high autogamy rates) shows a wide spectrum of low-efficiency visitors and pollinators (Table 3). These observations agree with Inoue (1988), who reported a relationship between abundance of inefficient pollinators and an increase in autopollinaton rate in Campanula. Similar changes have been reported for some taxa seen as colonizers in parts of the Northern Hemisphere. In many of those taxa, plasticity in pollinator attraction and outcrossing rate seems to have been the best evolutionary option (Inoue 1988; Stephenson et al. 2000; Kalisz et al. 2004).

ACKNOWLEDGMENTS. The authors thank G. Nieto Feliner for comments on the manuscript; F. Albers and C. Navarro for help with some Geraniaceae sequences; C. Roquet for help with the Multidivtime package; I. Sanmartín for help with DIVA analyses; M. J. Sanderson for help with R8S analyses; J. Castillo for drawings; A. Martin Ciudad for help with figures; F. Torres and M. Portillo (Universidad de Salamanca) and V. Rodriguez for help with insect determination; and K. Alpinar, S. Castroviejo, T. Egorova, I. Gillespie, G.G. Guittonneau, N. López, and M. Novoselova for help with specimens and literature. We are also grateful to the curators of the cited herbaria for kind assistance during our visits and for specimen loans. This work was partly financed by the Spanish Dirección General de Investigación Científica y Técnica (DGICYT) through the research project REN2000-0818/GLO and REN2003-04397/ GLO.

\section{Literature Cited}

Aedo, C., J. J. Aldasoro, and C. Navarro. 2002. Revision of Geranium sections Azorelloida, Neoandina, and Paramensia (Geraniaceae). Blumea 47: 205-297.

Aedo, C., F. Muñoz Garmendia, and F. Pando. 1998. World checklist of Geranium L. (Geraniaceae). Anales del Jardín Botánico de Madrid 56: 211-252. 
Akaike, H. 1974. A new look at the statistical model identification. IEEE Transactions of Automatic Control 19: 716-723.

Albers, F. 1996a. The generic status of Sarcocaulon (Geraniaceae). I. O. S. Bulletin 6: 51.

Albers, F. 1996b. The taxonomic status of the genus Sarcocaulon (Geraniaceae). South African Journal of Botany 62: 343-347.

Albers, F. and D. Löbbert. 1996. The status of the genus Sarcocaulon (Geraniaceae). XXII SAAB Congress, Abstract 36. Cape Town: Univ. of Stellenbosch.

Albert, M. J., A. Escudero, and J. M. Iriondo. 2005. Assesing ant seed predation in threatened plants: a case study. Acta Oecologica 28: 213220

Aldasoro, J. J., C. Aedo, and C. Navarro. 2000. Insect attracting structure on Erodium petals (Geraniaceae). Plant Biology 2: 471-481.

Aldasoro, J. J., C. Navarro, P. Vargas, and C. Aedo. 2001. Anatomy, morphology, and cladistic analysis of Monsonia L. (Geraniaceae). Anales del Jardín Botánico de Madrid 59: 75-100.

Aldasoro, J. J., C. Navarro, P. Vargas, Ll. Sáez, and C. Aedo. 2002. California, a new genus of Geraniaceae endemic to the southwest of North America. Anales del Jardín Botánico de Madrid 59: 209-216.

APG II. 2003. An update of the Angiosperm Phylogeny Group classification for the orders and families of flowering plants. Botanical Journal of the Linnean Society 141: 399-436.

Axelrod, D. 1972. Ocean-floor spreading in relation to ecosystematic problems. University of Arkansas Museum Occasional Papers 4: 15-68.

Axelrod, D. and P. H. Raven. 1978. Late Cretaceous and Tertiary vegetation history of Africa. Pp. 77-130 in Biogeography and ecology of Southern Africa, ed. M.J.A. Werger. The Hague: W. Junk

Baker, B. H. P., A. Mohr, and L. A. J. Williams. 1972. Geology of the eastern rift system of Africa. Geological Society of America Special Papers 136: 1-67.

Bakker, F. T., D. Helbrügge, A. Culham, and M. Gibby. 1998. Phylogenetic relationships within Pelargonium section Peristera (Geraniaceae) inferred from nrDNA and cpDNA sequence comparisons. Plant Systematics and Evolution 211: 273-287.

Bakker, F. T., A. Culham, L. Daugherty, and M. Gibby. 1999. A trnL-F phylogeny for species of Pelargonium (Geraniaceae) with small chromosomes. Plant Systematics and Evolution 216: 309-324.

Bakker, F. T., A. Culham, C. E. Pankhurst, and M. Gibby. 2000. Mitochondrial and chloroplast DNA-based phylogeny of Pelargonium (Geraniaceae). American Journal of Botany 87: 727-734.

Bakker, F. T., A. Culham, P. Hettiarachi, T. Touloumenidou, and M. Gibby. 2004. Phylogeny of Pelargonium (Geraniaceae) based on DNA sequences from three genomes. Taxon 53: 17-28.

Bakker, F. T., A. Culham, E. Marais, and M. Gibby. 2005. Nested radiation in Cape Pelargonium (Geraniaceae). Pp. 75-100 in Plant species-level systematics: new perspectives on patterns and process, eds. F. T. Bakker, L. W. Chatrou, B. Gravendeel and P. B. Pelser. Liechtenstein: Verlag.

Barraclough, T. G. 2006. What can phylogenetics tell us about speciation in the Cape flora. Diversity and Distribution 12: 21-26.

Bingham, R. A. and A. R. Orthner. 1998. Efficient pollination of alpine plants. Nature 391: 238-239.

Bingham, R. A. and T. A. Ranker. 2000. Genetic diversity in alpine and foothill populations of Campanula rotundifolia (Campanulaceae). International Journal of Plant Sciences 161: 403-411.

Blionis, G. J. and D. Vokou. 2002. Structural and functional divergence of Campanula spatulata subspecies on Mt Olympos (Greece). Plant Systematics and Evolution 232: 89-105.

Boesewinkel, F. D. 1988. The seed structure and taxonomic relationships of Hypseocharis Remy. Acta Botanica Neerlandica 37: 111-120.

Boesewinkel, F. D. 1997. Seed structure and phylogenetic relationships of the Geraniales. Botanische Jahrbücher für Systematik 119: 277-291.

Burke, A., N. Jürgens, and M. K. Seely. 1998. Floristic affinities of an inselberg archipielago in the Southern Namib desert-relic of the past, centre of endemism or nothing special. Journal of Biogeography 25: 311-317.

Clark, J. S. 1998. Why trees migrate so fast: confronting theory with dispersal biology and the paleorecord. American Naturalist 152: 204-224.

Cruden, R. W. 1977. Pollen-ovule ratios: a conservative indicator of breeding systems in flowering plants. Evolution 31: 32-46.

Deyrup, M. and E. S. Menges. 1997. Pollination ecology in the rare scrub mint Dicerandra frutescens (Lamiaceae). Florida Scientist 60: 143-157.

Dieckmann, B., G. Kuhn, R. Gersonde, and A. Mackensen. 2004. Middle Eocene to early Miocene environmental changes in the sub-Antartic Southern ocean: evidence from biogenic and terrigenous deposi- tional patterns at ODP site 1090. Global and Planetary Change 40: 295-313.

Dlusskii, G. M., N. V. Lavrova, and E. A. Erofeeva. 2000. The mechanisms of the restriction of pollinator range in the fireweed (Chamaenerion angustifolium) and two species of Geranium (G. palustre and G. pratense). Zhurnal Obshchei Biologii 61: 181-197.

El-Mouden, E. H., T. Slimani, K. Ben Kaddour, F. Laggarde, A. Ouhammou, and X. Bonnet. 2006. Testudo graeca feeding ecology in an arid and overgrazed zone in Morocco. Journal of Arid Environments 64: 422-435.

El-Oqlah, A. A. 1989. A revision of the genus Erodium L'Héritier in the Middle East. Feddes Repertorium 100: 3-4.

Elberling, H. and J. M. Olesen. 1999. The structure of high latitude plantflower visitor system: the dominance of flies. Ecography 22: 314-323.

Fay, M. F., C. Bayer, W. Alverson, A. Y. Bruijn, and M. W. Chase. 1998. Plastid $r b c L$ sequence data indicate a close affinity between Diegodendron and Bixa. Taxon 47: 43-50.

Felsenstein, J. 1985. Confidence limits on phylogenies: an approach using the bootstrap. Evolution 39: 783-791.

Felsenstein, J. 1988. Phylogenies from molecular sequences: inference and reliability. Annual Review of Genetics 22: 521-565.

Fitch, W. M. 1971. Toward defining the course of evolution: minimum change for a specific tree topology. Systematic Zoology 20: 406-416.

Fiz, O., V. Valcárcel, and P. Vargas. 2002. Phylogenetic position of Mediterranean Astereae and character evolution of daisies (Bellis, Asteraceae) inferred from nrDNA ITS sequences. Molecular and Phylogenetic Evolution 25: 157-171.

Fiz, O., P. Vargas, M. L. Alarcón, and J. J. Aldasoro. 2006. Phylogenetic relationships and evolution in Erodium (Geraniaceae) based on trnL-F sequences. Systematic Botany 31: 739-763.

Fordman, L. and D. Bridson. 1989. The herbarium handbook. Kew: Royal Botanic Gardens.

Gess, S. K. and F. W. Gess. 2006. Distribution of flower associations of pollen wasps (Vespidae, Masarinae) in Southern Africa. Journal of Arid Environments 57: 17-44.

Goertz, A. 2004. Bees and wildflowers in the Colorado Springs Area. http://www.cyberspace.org/-goertz/beep2.html

Goldblatt, P. and J. C. Manning. 2006. Radiation of pollination systems in the Iridaceae of sub-Saharan Africa. Annals of Botany 97: 317-344.

Goldblatt, P., J. C. Manning, and P. Bernhardt. 1995. Pollination biology of Lapeirousia subgenus Lapeirousia (Iridaceae) in Southern Africa. Annals of the Missouri Botanical Garden 82: 517-534.

Green, B. B. 1978. Comparative ecology of Geranium richardsonii and Geranium nervosum. Bulletin of the Torrey Botanical Club 105: 108-113.

Guittonneau, G. G. 1972. Contribution à l'étude biosystématique du genre Erodium L'Hér. dans le bassin méditérranéen occidental. Boissiera 20: $1-154$.

Guittonneau, G. G. 1990. Taxonomy, Ecology and Phylogeny of genus Erodium ĹHer. in the Mediterranean region. Pp. 71-91 in Proceedings of the International Geraniaceae Symposium, ed. P. Vorster. Stellenbosch, South Africa: Univ. Stellenbosch.

Herrera, J. 1991. Reproductive characteristics of a stable-dune therophyte community in Doñana (Southern Spain). Israel Journal of Botany 40: 295-304.

Hessing, M. B. 1989. Variation in self-fertility and floral characters of Geranium caespitosum (Geraniaceae) along an elevational gradient. Plant Systematics and Evolution 166: 225-241.

Higgins, S. I. and D. M. Richardson. 1999. Predicting plant migration rates in a changing world: the role of long-distance dispersal. American Naturalist 153: 464-475.

Huelsenbeck, J. P. and F. Ronquist. 2001. MrBayes: Bayesian inference of phylogenetic trees. Bioinformatics (Oxford, England) 17: 754-755.

Hutchinson, J. 1969. Evolution and phylogeny of flowering plants. London: Academic Press.

Inoue, K. 1988. Pattern of breeding-system change in the Izu Islands in Campanula punctata: Bumblebee-absence Hypothesis. Plant Species Biology 3: $125-128$.

Johnson, S. D. 1996. Pollination, adaptation and speciation models in the Cape flora of South Africa. Taxon 45: 59-66.

Johnson, S. D. and W. J. Bond. 1992. Habit dependent pollination success in a Cape orchid. Oecologia 91: 455-456.

Johnson, S. D. and K. E. Steiner. 2000. Generalization versus specialization in plant pollination systems. Trends in Ecology and Systematics 15: 140-143.

Kalisz, S., D. W. Vogler, and K. M. Hanley. 2004. Context-dependent 
autonomous self-fertilization yields reproductive assurance and mixed mating. Nature 430: 884-886.

Kandori, I. 2002. Diverse visitors with various pollinator importance and temporal change in the important pollinators of Geranium thunbergii (Geraniaceae). Ecological Research 17: 283-294.

Kers, L. E. 1968. Contributions to a revision of Monsonia (Geraniaceae). Botaniska Notiser 121: 44-50.

Kimura, M. 1980. A simple method for estimating evolutionary rates of base substitution through comparative studies of nucleotide sequences. Journal of Molecular Biology 16: 111-120.

Kishino, H., J. L. Thorne, and W. J. Bruno. 2001. Performance of a divergence time estimation method under of probabilistic model of rate evolution. Molecular Biology and Evolution 18: 352-361.

Kluge, A. G. 1989. A concern for evidence and a phylogenetic hypothesis for relationships among Epicrates (Boidae, Serpentes). Systematic Zoology 38: 7-25.

Lane, S. J., J. C. Alonso, J. A. Alonso, and M. A. Naveso. 1999. Seasonal changes in diet and diet selection of great bustards (Otis tarda) in north-west Spain. Journal of Zoology 247: 201-214.

Lavin, M., M. Thulin, J. N. Labat, and R. T. Pennington. 2000. Africa, the odd man out: molecular biogeography of Dalbergioid Legumes (Fabaceae) suggests otherwise. Systematic Botany 25: 449-467.

Link, D. A. 1990. The nectaries of Geraniaceae. Pp. 25-43 in Proceeding of the International Geraniaceae Symposium, ed. P. Voster. Cape Town: University of Stellenbosch

Loria, M. and I. Noi-Meir. 1980. Dynamics of some annual populations in a desert-loess plain. Israel Journal of Botany 28: 211-225.

Maddison, W. P. and D. R. Maddison. 1992. MacClade: Analysis of Phylogeny and Character Evolution. Version 3.0. Sunderland: Sinauer Associates.

Magallón, S. and M. J. Sanderson. 2001. Absolute diversification rates in angiosperm clades. Evolution 55: 1762-1780.

Manning, J. C. and P. Goldblatt. 1995. Cupid comes in many guises, the not-so-humble fly and a pollination guild in the Overberg. Veld and Flora 81: 50-52.

Manning, J. C. and P. Goldblatt. 1996. The Prosoeca peringueyi (Diptera: Nemestrinidae) pollination guild in Southern Africa: long-tongued flies and their tubular flowers. Annals of the Missouri Botanical Garden 83: $67-86$.

Manning, J. C. and P. Goldblatt. 1997. The Moegistorrhynchus longirrostris (Diptera: Nemestrinidae) pollination guild: long-tubed flowers and a specialized long-proboscid fly pollination system in Southern Africa. Plant Systematics and Evolution 206: 51-69.

Marloth, R. 1908. Some observations on entomophilous flowers. South African Journal of Science 4: 110-113.

McDonald, D. J. and J. J. A. Van der Walt. 1992. Observations on the pollination of Pelargonium tricolor, section Campylia (Geraniaceae). South African Journal of Botany 58: 386-392.

Medeiros, A. C. and H. St. John. 1988. Geranium hananense (Geraniaceae), a new species from Maui, Hawaian Islands. Brittonia 40: 214-220.

Moffett, R. O. 1979. The genus Sarcocaulon. Bothalia 12: 581-613.

Mulcahy, D. 1983. Pollen competition in a natural population. Pp. 330337 in Handbook of experimental pollination biology, eds. C. E. Jones and R. J. Little. New York: Academic Press

Müller, K. 2003. PRAP-parsimony ratchet analyses using PAUP. Bonn: program distributed by the author, Nees Institute, University of Bonn.

Müller, K. 2005. PRAP- computation of Bremer support for large data sets. BMC Evolutionary Biology 5: 58-68.

Nakano, C. and I. Washitani. 2003. Variability and specialization of plantpollinator systems in a northern maritime grassland. Ecological Research 18: 221-246.

Nixon, K. C. 1999. The parsimony ratchet, a new method for rapid parsimony analysis. Cladistics 15: 407-414

Nixon, K. C. and J. M. Carpenter. 1996. On simultaneous analysis. Cladistics 12: 221-242.

Nylander, J. A. A. 2002. MrModeltest v1.1b. Program distributed by the author. Department of Systematic Zoology, Uppsala University. http://www.ebc.uu.se/systzoo/staff/nylander.html

Olmstead, R. G., H. J. Michaels, K. M. Scott, and J. D. Palmer. 1992. Monophyly of the Asteridae and identification of their major lineages inferred from DNA sequences of rbcL. Annals of the Missouri Botanical Garden 79: 249-265.

Pax, D. L., R. A. Price, and H. J. Michaels. 1997. Phylogenetic position of the Hawaiian Geraniums based on $r b c \mathrm{~L}$ sequences. American Journal of Botany 84: 72-78.
Philipp, M. 1985. Reproductive biology of Geranium sessiliflorum. 1. Flower and flowering biology. New Zealand Journal of Botany 23: 567580 .

Philipp, M. and T. Hansen. 2000. The influence of plant and corolla size on pollen deposition and seed set in Geranium sanguineum (Geraniaceae). Nordic Journal of Botany 20: 129-140.

Pleasants, J. M. 1980. Competition for bumblebee pollinators in Rocky Mountain plant communities. Ecology 61: 1446-1459.

Pons, A. and P. Quezel. 1985. The history of the flora and vegetation and past and present human disturbance in the mediterranean region. Pp. 25-43 in Plant Conservation in the Mediterranean Area, ed.C. Gomez Campo. Dordrecht: W. Junk.

Price, R. A. and J. D. Palmer. 1993. Phylogenetic relationships of the Geraniaceae and Geraniales from $r b c \mathrm{~L}$ sequence comparisons. Annals of the Missouri Botanical Garden 80: 661-671.

Proctor, M., P. Yeo, and A. Lack. 1996. The natural history of pollination. Portland, Oregon: Timber Press.

Rama Devi, D. 1991. Floral anatomy of Hypseocharis (Oxalidaceae) with a discussion of its systematic position. Plant Systematics and Evolution 177: 161-164.

Ricklefs, R. E. and S. S. Renner. 2000. Evolutionary flexibility and flowering plant familial diversity: a comment on Dodd, Silvertown, and Chase. Evolution 54: 1061-1065.

Ridley, H. N. 1930. The dispersal of plants throughout the world. Co. Ashford, Kent: L. Reeve.

Ronquist, F. 1997. DIVA version 1.1. Computer program and manual available by anonymous FTP from Uppsala University (http:// www.ebc.uu.se/systzoo/research/diva/diva.html).

Ronquist, F. and J. P. Huelsenbeck. 2003. MrBayes 3: Bayesian phylogenetic inference under mixed models. Bioinformatics (Oxford, England) 19: 1572-1574.

Rösch, M. W. 1977. Enkele plantekologiese aspekte van die Hester Malan natuurreservaat, Namakwaland. M.Sc. Thesis. Pretoria: University of Pretoria.

Rösch, M. W. 1978. Anemochorie by enkele plantspecies van die Hester Malan natuurreservaat, Namakwaland. South African Journal of Biological Society 19: 26-37.

Rutschmann, F. 2004. Bayesian molecular rate using PAML/ Multidivtime. A step by step manual. University of Zurich. Switzerland. (http://statgen.ncsu.edu/thorne/multidivtime.html).

Saitou, N. and M. Nei. 1987. The Neighbor-Joining method: A new method for reconstructing phylogentic trees. Molecular Biology and Evolution 4: 406-425.

Sanderson, M. J. 2002. Estimating absolute rates of molecular evolution and divergence times: a penalized likelihood approach. Molecular Biology and Evolution 19: 101-109.

Savolainen, V., M. F. Fay, D. C. Albach, A. Backlund, M. van der Bank, K. M. Cameron, S. A. Johnson, M. D. Lledó, J. C. Pintaud, M. Powell, M. C. Sheahan, D. D. Soltis, P. S. Soltis, P. Weston, W. M. Whitten, K. J. Wurdack, and M. W. Chase. 2000a. Phylogeny of the eudicots: a nearly complete familial analysis based on $r b c L$ gene sequences. Kew Bulletin 55: 257-309.

Savolainen, V., M. W. Chase, S. B. Hoot, C. M. Morton, D. E. Soltis, C. Bayer, M. F. Fay, A. De Bruijn, S. Sullivan, and Y.-L. Qiu. 2000b. Phylogenetics of flowering plants based upon a combined analysis of plastid $a t p B$ and $r b c L$ gene sequences. Systematic Biology 49: 306362.

Scheltema, A. G. and J. J. A. Van der Walt. 1990. Taxonomic revision of Pelargonium sect. Jenkinsonia (Geraniaceae). South African Journal of Botany 59: 259-264

Schemske, D. W. 1983. Limits to specialization and coevolution in plantanimal mutualisms. Pp. 67-109 in Coevolution, ed. M. H. Nitecki. Chicago: Chicago Univ. Press.

Shmida, A. 1981. Mediterranean vegetation in California and Israel: similarities and differences. Israel Jornal of Botany 30: 105-123.

Shmida, A. and S. Ellner. 1983. Seed dispersal on pastoral grazers in open mediterranean chaparral. Israel Jornal of Botany 32: 147-159.

Siesser, W. G. 1980. Late Miocene origin of the Benguela upwelling system of northern Namibia. Science 208: 283-285.

Simmons, M. P. 2004. Independence of alignment and tree search. Molecular Phylogenetics and Evolution 31: 874-879.

Simón, J., M. Estrada, C. Blanché, and J. Molero. 2000. Biologia de la conservació de tres espècies endèmiques del Parc Natural de Sant Llorenç del Munt i l'Obac. Monografies del Servei de Parcs Naturals de la Diputació de Barcelona 29: 33-43.

Skorupa, J. P., R. L. Hothem, and R. W. DeHaven. 1980. Foods of breeding 
tricolored blackbirds in agricultural areas of Merced County, California. The Condor 82: 465-467.

Slanis, A. C. and A. Grau. 2001. El género Hypseocharis (Oxalidaceae) en la Argentina. Darwiniana 39: 343-352.

Smissen, R. D. 2003. Phylogenetic analysis of ITS sequences suggests a Pliocene origin for the bipolar distribution of Scleranthus (Caryophyllaceae). Australian Systematic Botany 16: 301-315.

Soholt, L. F. 1973. Consumption of primary production by a population of Kangaroo rats (Dipodomys merriami) in the Mojave desert. Ecological Monographs 43: 357-376.

Soltis, D. D., P. S. Soltis, M. W. Chase, M. E. Mort, D. C. Albach, M. Zanis, V. Savolainen, W. H. Hahn, S. B. Hoot, M. F. Fay, M. Axtell, S. M. Swensen, L. M. Prince, W. J. Kress, K. C. Nixon, and J. S. Farris. 2000. Angiosperm phylogeny inferred from $18 \mathrm{~S} \mathrm{rDNA}, r b c \mathrm{~L}$, and $a t p \mathrm{~B}$ sequences. Botanical Journal of the Linnean Society 133: 381-461.

Stamp, N. E. 1984. Self-burial behaviour of Erodium cicutarium seeds. Journal of Ecology 72: 611-620.

Stamp, N. E. 1989. Seed dispersal of four sympatric grassland annual species of Erodium. Journal of Ecology 77: 1005-1020.

Stafford, P. J. and S. Blackmore. 1991. The Northwest European pollen flora, 46. Geraniaceae. Review of Palaeobotany and Palynology 69: 4978 .

Stephenson, A. G., S. V. Good, and D. W. Vogler. 2000. Interrelationships among inbreeding depresion, plasticity in the self-incompatibility system, and the breeding system of Campanula rapunculoides L. (Campanulaceae). Annals of Botany 85(supl.): 211-219.

Struck, M. 1997. Floral divergence and convergence in the genus Pelargonium (Geraniaceae) in Southern Africa: ecological and evolutionary considerations. Plant Systematics and Evolution 208: 71-97.

Struck, M. and J. J. A. Van der Walt. 1996. Floral structure and pollination in Pelargonium. Pp. 631-638 in The Biodiversity of African Plants, eds. L. J. G. van der Maesen, X. M. van der Burgt and J. M. van Medenbach de Rooy. The Hague: Kluwer Academic.

Swofford, D. L. 2002. PAUP*: Phylogenetic analysis using parsimony (*and other methods), Version 4.0b10. Sunderland: Sinauer Associates.

Taberlet, P., L. Gielly, G. Pautou, and J. Bouvet. 1991. Universal primers for amplification of three non-coding regions of chloroplast DNA. Plant Molecular Biology 17: 1105-1109.

Thompson, J. D., T. J. Gibson, F. Plewniak, F. Jeanmougin, and D. G. Higgins. 1997. The CLUSTAL_X windows interface: flexible strategies for multiple sequence alignment aided by quality analysis tools. Nucleic Acids Research 25: 4876-4882.

Thorne, J. L., H. Kishino, and I. S. Painter. 1998. Estimating the rate of evolution of the rate of molecular evolution. Molecular Biology and Evolution 15: 1647-1657.

Thorne, J. L. and H. Kishino. 2002. Divergence time and evolutionary rate estiation with multilocus data. Systematic Biology 51: 689-702.

Tofts, R. J. 2004. Biological flora of the British Isles. Geranium robertianum L. Journal of Ecology 92: 537-555.

Totland, O. 1993. Pollination in alpine Norway: flowering phenology, insect visitors, and visitation rates in two plant communities. Canadian Journal of Botany 71: 1072-1079.

Touloumenidou, T., F. T. Bakker, and F. Albers. 2007. The phylogeny of Monsonia. Plant Systematics and Evolution 264: 1-14.

Van Campo, E. 1989. Flore pollinique du Miocene superieur de Venta del Moro. Acta Palinologica 1: 9-32.

Van der Niet, J. J. A., S. D. Johnson, and H. P. Linder. 2006. Macroevolutionary data suggest a role for reinforcement in pollination system shift. Evolution 60: 1596-1601.

Van der Walt, J. J. A., D. J. McDonald, and N. Van Wik. 1990. A new species of Pelargonium with notes on its ecology and pollination biology. South African Journal of Botany 56: 467-470.

Van Reede, K. and M. W. Van Rooyen. 1999. Dispersal Biology of Desert Plants. Berlin: Springer.

Van Zinderen Bakker, E. M. 1969. Observations on the distribution of Ericaceae in Africa. Argumenta Geographica 12: 89-97.

Van Zinderen Bakker, E. M. 1975. The origin and palaeoenvironment of the Namib Desert biome. Journal of Biogeography 2: 65-73.

Venter, H. J. T. 1979. A monograph of Monsonia L.(Geraniaceae). Mededlingen Landbouwhoogeschool Wageningen, Nederland 79: 1-128.

Venter, H. J. T. 1983. Phytogeography and interspecies relationships in Monsonia L. (Geraniaceae). Bothalia 14: 865-869.

Vogel, S. 1954. Blütenbiologische Typen als Elemente der Sippengliederung. Jena: Gustav Fischer.
Vogel, S. 1998. Remarkable nectaries: structure, ecology, organophyletic prespectives. Miscellaneous cases. Flora 193: 225-248.

Ward, J. D., M. K. Seely, and N. Lancaster. 1983. On the antiquity of the Namib. South African Journal of Science 79: 175-183.

Wikström, N., V. Savolainen, and M. W. Chase. 2001. Evolution of Angiosperms: calibrating the family tree. Proceedings of the Royal Society of London (serie B) 268: 2211-2220.

Willson, M. F., L. J. Miller, and B. J. Rathcke. 1979. Floral display in Phlox and Geranium: adaptative aspects. Evolution 33: 52-63.

Yang, Z. 1997. PAML: a program package for phylogenetic analysis usng maximum likelihood. Computer Applied BioScience 13: 555-556.

Yang, Z. and B. Rannala. 1997. Bayesian phylogenetic inference using DNA sequences: a Markov Chain Monte Carlo method. Molecular Biology and Evolution 14: 717-724.

Yeo, P. F. 1973. The biology and systematics of Geranium, sections Anemonifolia Knuth, and Ruberta Dum. Botanical Journal of the Linnean Society 67: 285-346.

Yeo, P. F. 1984. Fruit-discharge type in Geranium (Geraniaceae): its use in classification and its evolutionary implications. Botanical Journal of the Linnean Society 89: 1-36.

Yeo, P. F. 1990. The classification of Geraniaceae. Pp 3-18 in Proceeding of the International Geraniaceae Symposium, ed. P. Voster. Cape Town: Univ. of Stellenbosch.

Yumoto, T. 1986. The ecological pollination syndromes of insectpollinated plants in alpine meadow. Ecological Research 1: 83-95.

Zeide, B. 1976. Dispersal patterns in Erodium hirtum Willd. Israel Jornal of Botany 25: 221-224.

Zietsman, P. C. 1993. Pollination in Pelargonium dolomiticum Knuth (Geraniaceae). South African Journal of Botany 59: 259-264.

APPENDIX 1. Samples and accessions provided for $\operatorname{trn} L-F$ and $r b c L$ used in the present study, including their locality, voucher and herbarium number and GenBank accession numbers. Data are presented in the following sequence: taxon name, locality, voucher, herbarium number and GenBank accession numbers (new sequences indicated by bold type) for $t r n L-F$ and $r b c L$ region. "- " indicates no sequence for the DNA region.

Balbisia microphylla (Phil.) Reiche: CHILE, Antofagasta, W of Paposo, Aedo 6970 (MA), DQ459009, - . Bersama lucens Scyscyl, GenBank, 一, AJ235774.

California macrophylla Aldas., Navarro, Vargas, Sáez \& Aedo: U.S.A., California, Riverside Co., Temescal Valley, Gillespie 10 (MA), DQ072013, DQ452869. Crossosoma bigelovii S. Watson: USA, Arizona, Álvarez SS137, DQ452888, —; C. californicum Nutt.: GenBank, —, L11179.

Erodium absinthioides Willd.: TURKEY, Bursa, Uludag, Nieto Feliner 1580 (MA-393124), DQ452876, DQ072034; E. alpinum (Burm f.) L'Hér.: ITALY, Abruzzo, Mt. Rosa Pinnola, Bisegna, L'Aquila, Conti 1656 (MA), DQ072029, - ; E. antariense Rouy: MOROCCO, High Atlas, Tizi-n-AïtHamed, Güemes 1549 (MA), DQ072078, DQ452881; E. arborescens (Desf.) Willd.: TUNISIA, Skhira, Aldasoro 3053 (MA), DQ072018, —; E. asplenioides (Desf.) Willd: TUNISIA, La Kesra-Darsole, Timbal s.n. (MPU), DQ072065, - ; E. aureum Carolin: AUSTRALIA, Coolgardie, Eyre Higway, $59 \mathrm{Km} \mathrm{W}$ of Madura, Archer 15 (MEL-2039223), DQ072066, -; E. botrys (Cav.) Bertol.: U.S.A., California, San Francisco, Mt. Tamalpais, Castroviejo et al. 14575 (MA), DQ072049, -; E. brachycarpum Godr.: SPAIN, Madrid, Rozas de Puerto Real, López 499 (MA), DQ072050, DQ452879; E. ciconium (L.) L'Hér.: ITALY, Abruzzo, L'Aquila, pr. Santo Stéfano de Sessanio, Aedo et al. 8108 (MA), DQ072039, DQ452875; E. cicutarium (L.) L'Hér. ex Aiton (1): SPAIN, Salamanca, Fuente de San Esteban, Aedo et al. 4931 (MA), DQ072052, DQ452882; E. cicutarium (2): AUSTRALIA, Mt. Annan Botanic Garden, D'Aubert 405 (NSW-213829), DQ072051, -; E. corsicum Léman: FRANCE, Corsica, Piana, plage di Ficajola, Serra and Bort 4897 (MA-623612), DQ072059, -; E. cossonii Guitt. \& Mathez: MOROCCO, High Atlas, Tiz-n-Test, Fernández Casas et al. 3277 (MA-252363), DQ072073, - ; E. crinitum Carolin: AUSTRALIA, Buraminya, between Roe and Coolgardie, Archer 27069213 (MEL-2015744), DQ452897, DQ452877; E. cygnorum Nees: cultivated in MA from seeds collected in Great Victoria Desert (Australia), Aldasoro 2842 (MA), DQ072044, DQ452878; E. daucoides Boiss.: SPAIN, Jaen, Cortijos Nuevos, El Yelmo, Navarro et al. 2307 (MA-625205), DQ072095, -; E. gaillardotti Boiss.: TURKEY, Malatya, $27 \mathrm{Km}$ from Gürün to Darende, MuñozGarmendia et al. 4567 (MA), DQ072035, —; E. geoides A. St.-Hil.: CHILE, Coquimbo, Choapa province, border of Petarca province, Taylor 10620 (MO), DQ072048, -; E. glaucophyllum (L.) L'Hér. ex Aiton: TUNISIA, 14 Km of Moulares, Aldasoro 3000 (MA), DQ072016, DQ452870; E. gruinum 
(L.) L'Hér.: JORDANIA, Gerassa (Jerash), Vargas (MA), DQ072037, DQ452874; E. guttatum (Desf.) Willd.: TUNISIA, Feriana, Aldasoro 2973 (MA), DQ072026, 一; E. hoefftianum C. A. Mey.: TURKEY, Göreme, Ask Vadisi, dept. Nevsehir, Muñoz-Garmendia et al. 4626 (MA), DQ072033, DQ452872; E. jahandiezianum Emb., Maire \& Weiller: MOROCCO, AntiAtlas, Igherm, Gómiz s.n. (BC), DQ072022, —; E. malacoides (L.) L'Hér. ex Aiton: SPAIN, Cádiz, Zahara de la Sierra, Navarro 3424 (MA-685245), DQ072071, DQ452883; E. neuradiifolium Delile ex Godr., SPAIN, Albacete, Letur, Álvarez 1239 (MA-591697), DQ072069, —; E. oxyrhynchum M. Bieb., cultivate in MA from seeds collected in Egypt, Cairo-Suez Desert Road, Aldasoro 3487 (MA), DQ072023, —; E. paularense Fern. Gonz. \& Izco, SPAIN, Guadalajara, Cañamares, Atienza, Aedo 4097 (MA-588866), DQ072077, —; E. pelargoniflorum Boiss. \& Heldr. in Boiss.: cultivate in MA from seeds collected in Ermenek, SE Turkey, Aldasoro 2838, 9150 (MA), DQ072041, DQ452873; E. sebaceum Delile: MOROCCO, Boumia, 8 km NW of Er-Rachidia, Podlech 43213 (MA-464889), DQ072102, DQ452880; E. stephanianum Willd.: CHINA, Qinghai, Nangqên Xian, NW of Jangkar (upper Mekong), between Jangkar and Yushu, Ho et al. 2892 (MO), DQ072027, DQ452871; E. texanum A. Gray (1): cult. in MA from seeds collected in Yavapai Co., Arizona, USA, Aldasoro 3492 DQ072026, -; E. texanum A. Gray (2): GenBank, -, L14693; E. tordylioides (Desf.) L'Hér.: SPAIN, Cádiz, Zahara de la Sierra, Navarro 3425 (MA685246), DQ072100, -; E. "variabile" (presumed hybrid E. reichardii x E. corsicum), GenBank, 一, L14694.

Francoa appendiculata Cav.: CHILE, La Araucanía, $8 \mathrm{Km} \mathrm{N}$ of Yupehue, Aedo 7192 (MA), DQ452889, —; F. sonchifolia (Willd.) Cav.: GenBank, 一, L11184. Geranium aculeolatum Oliv.: cultivated in MA from seeds collected in Mt Kilimanjaro, Aizpuru s.n. (MA), DQ452905, —; G. albanum M. Bieb.: cultivated in MA from seeds collected in Georgia, Aedo 3864 (MA593799), DQ452915, DQ452884; G. atlanticum Boiss.: MOROCCO, Beni-Snassen, Maison Forrestiére Ain-Almon Jury 15548 (MA643260), DQ452924, —; G. argenteum L.: cultivated in MA from seeds collected in France, Aedo, CA3870 (MA), DQ072050, -; G. austroapenninum Aedo: ITALY, Abruzos, Herrero et al. 2018 (MA), DQ452929, —; G. asphodeloides Burm. F.: TURKEY, Bandirma, Erdek, Castroviejo 15201 (MA), AY944424, —; G. bicknellii Britton: USA, Smooth Rock Falls, Cousineau 43581 (MA643259), DQ452925, -; G. biuncinatum Kokwaro: cultivated in MA from seeds collected between Hilla and Attuba (Yemen), Wood 3126 (MA), DQ452926, DQ452885; G. brasiliense Progel in Mart.: BRASIL, Rio de Janeiro, Itatiaia, Alves 2762 (MA), DQ452901, —; G. brycei N. E. Br.: Aedo 4474 (MA), DQ452911, -; G. caffrum Eckl. \& Zeyh.: cultivated in MA from seeds collected in the Cape, Aedo 4472 (MA), DQ452917, -; G. californicum G. L. Jones \& F. L. Jones: cultivated in MA from seeds collected in California, Aedo 5450, DQ452927, —; G. cataractarum Coss.: MOROCCO, Middle Atlas, S de Timhadit, Aedo 4234 (MA593420), DQ452916, —; G. cazorlense Heywood: SPAIN, Jaen, Cazorla Aedo 2587 (MA), DQ452930, -; G. cinereum Cav. : SPAIN, Huesca, Ordesa, Vargas 335pv02, DQ452931, —; G. columbinum L.: SPAIN, Gerona, Sierra del Montsiá, San Carles de la Rapita, Velayos et al. 9387 (MA626513), DQ452910, —; G. core-core Steud.: CHILE, Antofagasta, Toconao, Aedo 7006 (MA), DQ452921, -; G. costaricense Steud.: cultivated in MA from seeds collected in Chirripó, Costa Rica, Castroviejo 15137, DQ452912, —; G. divaricatum: TURKEY, Ghumushane, Ak Dagh, Aedo 468, DQ452906, DQ452886; G. dolomiticum Rothm.: SPAIN, León, Priaranza, Ferradillo, Aedo 2433 (MA), DQ452903, —; G. endressii J. Gay: FRANCE, Pyrénées Atlantiques, Béhorléguy, Aedo 2966 (MA593743), DQ452920, —; G. gracile Ledeb. ex Nordm.: TURKEY, Trabzon, Sumelas, Valcárcel 370VV01, DQ452918, G. lucidum L.: MOROCCO, Xauen, Jbel Lakra, Hauta-elKasdir, Aedo 4118 (MA593333), DQ452914, —; G. macrorrhizum L. (1): BULGARIA, Rhodope Mts, Aedo 10351, DQ072043, -; G. macrorrhizum L. (1): GenBank, -, L14696; G. nanum Coss ex Batt.: MOROCCO, Atlas Medio, Jbel Bou Iblane, Aedo 4199 (MA593345), DQ452904, —; G. nodosum L. : ITALY, Abruzzo, Ceppo, Herrero et al. 1995, DQ452922, —; G. palmatum Cav.: MADEIRA, Porto Moniz, Chao Ribeira, Vargas 125PV98 (MA), AY944418, -; G. phaeum L.: FRANCE, Xuberoa, Aedo 2967 (MA), DQ452902, —; G. pusillum L. (1): MOROCCO, Taffert, Atlas Medio Aedo 4144 (MA593417), DQ452907, -; G. pusillum L. (2): GenBank, 一, AF167151; G. pyrenaicum Burm. F.: MOROCCO, Middle Atlas, S Timhadit, Aedo 4235, (MA593341), DQ452908, -; G. reflexum L.: ITALY, Abbruzi, Il Aquila, Aldasoro 3443 (MA), DQ452909, -; G. robertianum L., GenBank, - , AF167152; G. rotundifolium L.: TURKEY, Evciler, Kaz Dagh, Castroviejo 15237 (MA643798), DQ452928, -; G. sylvaticum L.: SPAIN, Valle de Arán, Bagergue, Aedo 4842 (MA), DQ452923, -; G. tuberosum L.: TURKEY, Ermenek, Aldasoro A9140, DQ452919, DQ452887; G. yesoense Franch.\& Sav: JAPAN, Honshu, Toyama-ken, Tateyama-cho, Mt Tsurugidake, Estébanez 182 (MA690990), DQ452913, - . Greyia sutherlandii Hook.
\& Harv.: cultivate in BC from seeds collected in South Africa,Vargas 9e4pv99, DQ072073, —; G. radlkoferi Szyszyl., GenBank, —, L11185. Hypseocharis bilobata Killip: PERU, Cuzco, Aedo 5256B (MA), DQ452890, —; Hypseocharis sp.: GenBank, —, L14699.

Melianthus major L (1): GenBank, DQ072052, —; M. major (2): GenBank, -, AJ402972; M. major (3): GenBank, -, AJ403027. Monsonia angustifolia E. Meyer ex A. Richard: SOUTH AFRICA, N Transvaal, Penther 2218 (W), DQ452891, -; M. camdeboense (Moffet) Albers: cultivated in South Africa, Kirstenbosch, Aldasoro s.n. DQ452900; M. emarginata (L. fil.) L'Herit. (1): cultivated in MA from seeds taken in South Africa, Aldasoro s.n., DQ452893, -; M. emarginata (2): GenBank, -, L14701; M. heliotropiodes (Cav.) Boiss.: ALGERIA, Oujda, Molero, BC-804188, DQ452897, —; M. ignorata Merxm. \& Schr.: NAMIBIA, Windhoek, Sossusvlei, Vargas 421PV02 (MA), DQ072010, —; M. marlothii (Engl.) Albers: NAMIBIA, Swakopmund, Khan canyon, Vargas 423PV03, (MA), DQ452899, DQ452867; M. multifida (E. Mey. ex Knuth) Albers: SOUTH AFRICA, Kirstensbosch Gassner 25-8-77 (MA), DQ452898, —; M. nivea (Decaisne) Webb, MOROCCO, Taoujgalt, High Atlas, S of the M'goun Mt., Staudinger and Finckh s.n. (STAUD), DQ452895, DQ452868; M. parvifolia Schinz, NAMIBIA, Naroep, Great Buchsmanland Schlechter s.n. (W), DQ452894, - ; M. praemorsa E. Mey. ex Knuth, SOUTH AFRICA, Natal, Clairmont, Wood s.n.(W) DQ452892, -; M. speciosa L., cultivated in the Jardin Botanique National de Belgique, Billier s.n. (MA), DQ452896, —; M. vanderietiae (L. Bol.) Albers: GenBank, AF167150, L14705.

Pelargonium althaeoides L'Herit.: GenBank, Z95299, —; P. australe Willd.: GenBank, Z95280, —; P. cotyledonis (L.) L'Herit.: GenBank, Z95294, L14703; P. capitatum (L.) L'Herit.: GenBank, -, L14702; P. elongatum (Cav.) Salisb., GenBank, AF167146, —; P. exstipulatum (Cav.) L'Herit.: GenBank, Z95284, L14704; P. pseudofumarioides Knuth: GenBank, Z95295, —; P. rapaceum (L.) L'Herit.: GenBank, AF036065, —; P. redactum Vorster, GenBank AF167142, —; P. whytei Bakker, GenBank, AF167142, —. Viviania marifolia Cav., GenBank, - , L14707; Wendtia gracilis Meyen., CHILE, O’Higgins, Rancagua, Aedo 7065 (MA685239), DQ459010, —; W. gracilis, GenBank, -, L14708.

APPENDIX 2. Inferred reproduction type and P/O indexes in Geraniaceae and Hypseocharitaceae. Reproduction types, $\mathrm{X}$ : generally allogamous, F: facultative, A: generally autogamous, (D): dioecious, (GD): gynodioecious, n: P/O index unknown. Species with "*" were cultivated, studied and bagged for automatic selfing tests and dioecy observation, in the rest autogamy was deduced from $\mathrm{P} / \mathrm{O}$ and dioecy from herbarium sheets.

California macrophylla: A*, 52, U.S.A., California, Riverside Co., Temescal Valley, Gillespie s.n. (MA).

Erodium absinthioides: $X^{*}$ (D), 736, TURKEY, Ulu Dagh, Bursa, Aldasoro et al. 9193 (MA); E. acaule: X, 783, ITALY, Sicilia, Castroviejo et al. 16583 (MA); E. aguilellae López Udias, Fabregat \& G. Mateo: X*, 840, SPAIN, Castellón, Onda, Sierra de las Pedrizas, Aldasoro and Alarcón 9211 (MA); E. alnifolium Guss.: A*, 221, TUNISIA, Sejenane, Aldasoro et al. 2865 (MA); E. alpinum: $\mathrm{X}^{*}$ (D), 890, ITALY, L'Aquila, Abruzzo, Aedo et al. 8256 (MA); E. antariense: $X^{*}, 519$, MOROCCO, Tizi-n-Aït Hamed, Güemes et al. 1549 (MA); E arborescens: X-F*, 449, EGYPT, Avdat, Liston (HUJ); TUNISIA, Bizerta, Aldasoro s.n (MA); E. asplenioides: $X^{*}, 1238$, TUNISIA, Sejenane, Aldasoro et al. 2935 (MA); E. astragaloides Boiss. \& Reut.: X*, 699, SPAIN, Granada, Trevenque, Dilar, Navarro et al. 2246 (MA); E. aureum: A*, 102, AUSTRALIA, Axehead Qarry, Gardner-Torrens (MA); E. beketowi Schmalh: X (D), 430, RUSSIA, Stavropol, Biespors, Smabanova (LE); E. boissieri Coss., $\mathrm{X}^{*}, 777$, SPAIN, Granada, Trevenque, Aedo et al. 7829 (MA); E. botrys: A*, 136, Spain, Salamanca, Aldasoro and Alarcón 3470 (MA); E. brachycarpum: A*, 80, SPAIN, Madrid, Rozas de Puerto Real, Aldasoro and Alarcón 3477 (MA); E. carolinianum Aldasoro \& al.: A*, 94, AUSTRALIA, Ayers Rock, Lazarides 474 (NSW); E. carvifolium Boiss. \& Reut.: X*, 761, SPAIN, Burgos, Navas del Pinar, Aldasoro and Alarcón 8830 (MA); E. cazorlanum Heiwood: X*, 582, SPAIN, Granada, Mt Jabalcón, Aldasoro and Alarcón 9219 (MA); E. cedrorum Schott \& Kotschy: X (D), 334, TURKEY, Ala Dag, Nidge, Spitzberger 121(W); E. chium (L.) Willd: A*, 316, SPAIN, Ronda, Tavirana, Navarro et al. 3450 (MA); E. chrysanthum L'Hér.: X* (D), 397, GREECE, Killíni, Hörandl \& Hadacek 7612 (W); E. ciconium: A*, 95, SPAIN, Madrid, Aldasoro 949 (MA); E. cicutarium: A*, 59, SPAIN, Salamanca, Aldasoro s.n. (MA); E. corsicum: X-F*, autocompatibility increases in autumn, 617, Cult. in MA, plants collected in Corsica, Ajaccio, Aldasoro s.n. (MA); E. cossoni: X,1267, MOROCCO, Taroundant, High Atlas, Charpin et al., 324 (W); E. crassifolium (Desf.) DC.: F*, 231, TUNISIA, Aldasoro 3069 (MA); E. crinitum: A*, 73, AUSTRALIA, Olimpic Damp Mine, Badman s.n. (MA); E. cygnorum: A* 75, AUSTRALIA, Mukimbudin, Dodd 559 (MEL); E. daucoides: $X^{*}$, 
563, SPAIN, Burgos, Sargentes de Lora, Aldasoro and Alarcón 8831 (MA); E. foetidum (L.) L'Hér.: $\mathrm{X}^{*}, 737$, SPAIN, Teruel, Javalambre, Aldasoro and Alarcón 9213 (MA); E. gaillardotii: X* (D), 353, TURKEY, Malatya, Muñoz et al. 4567 (MA); E. geoides: A, 32, CHILE, Coquimbo, Taylor s.n. (MO); E. glandulosum (Cav.) Willd.: X*, 516 (Simón et al. 2000); 690, SPAIN, Palencia, Valdecebollas, Aldasoro and Alarcón 8832 (MA); E. glaucophyllum: F*, 173, TUNISIA, Moulares, Aldasoro 3043 (MA); E. gruinum: A*, 198, JORDANIA, Gerassa, Vargas s.n. (MA); E. guicciardii Boiss.: X* (D), 312, TURKEY, Karaburun, Aldasoro et al. 9178 (MA); E. guttatum: F*, autocompatibility increases in autumn, P:O mean: 208 (sd: 106); april: 294 (sd: 110), june: 144 (sd: 63.7), october: 87 (sd 9.2), Cult. in MA garden from seeds taken in Morocco, Azrou, Jury s.n. (MA); Cultivated in MA garden from plants taken in Tunisia, Kabili, collected by Aldasoro 3024 (MA); E. hendrickii Alpinar: X (D), 433, TURKEY, Lazistan, Aucher-Eloy (P); Gumushane, Alpinar s.n. (ISTE); E. hoeftianum: A*, 108, TURKEY, Göreme, Nevsehir, Muñoz et al. 4626 (MA); E. jahandiezanum: X-F*, 506, MOROCCO, Agadir, Titeki, Blanché et al. 9376 (SEV); E. janszii Alarcón et al.: A*, 44, AUSTRALIA, Fraser Range, Helms s.n. (MEL); E. laciniatum (Cav.) Willd.: $\mathrm{A}^{*}, 258$, Cult. in MA, MOROCCO, unknown procedence (MA); E. lucidum Lapeyr.: $X^{*}, 684$, SPAIN, Lérida, Senet, Aldasoro and Alarcón 8838 (MA): E. macrocalyx (G. López) López Udias et al.: X*, 414, SPAIN, Cuenca, Tragacete, Aldasoro and Alarcón 9216 (MA); E. malacoides: A*, 175, SPAIN, Salamanca, Aldasoro and Alarcón 3472 (MA); E. manescavii Coss.: X*, 722, FRANCE, Bilheres, Aldasoro and Alarcón 8837 (MA); E. maritimum (L.) L'Hér. ex Aiton: A, 68, SPAIN, Formentera, Sáez s.n. (MA); E. moschatum (L.) L'Hér. ex Aiton: A, 181, SPAIN, Madrid, Aldasoro s.n. (MA); E. mouretii Pit.: $X^{*}, 1255$, SPAIN, Huelva, Alange, Moreno 9 (MA); E. nervulosum L'Hér.: X, 574, ITALY, Puglia, Steinberg s.n. (MAF); E. neuradiifolium: A*, 102, MOROCCO, Oujda, Mateos and Valdés s.n. (SEV); E. oxyrrhynchum: A* 76, ARMENIA, Aragat Mts., Herrero s.n. (MA); E. paularense: X*, 1023, SPAIN, Guadalajara, Cañamares, Aldasoro and Alarcón 8835 (MA); E. pelargoniflorum: X*, 603, TURKEY, Ermenek-Anamur, Aldasoro et al. 9150 (MA); E. recoderi Auriault \& Guitt.1: X*, 1728, SPAIN, Cádiz, Tavirana, Aldasoro and Alarcón 5015 (MA); E. recoderi 2: X*, 712, SPAIN, Málaga, Puerto de las Palomas, Aldasoro and Alarcón 5019 (MA); E. rupicola (Boiss.) Boiss.: X, 991, SPAIN, Almería, Calar Alto, Aldasoro and Alarcón 9218 (MA); E. reichardii (Murray) DC.: X-F*, autofertility higher in atumn, 540, Cult. in MA plants collected in Spain, Mallorca, Formentor, Aldasoro and Alarcón 9222 (MA); E. rupestre (Pourr. ex Cav.) Cadevall: X*, 1049, SPAIN, Lérida, Trem, Sierra de Gurp, Aedo 4782 (MA); E. ruthenicum M. Bieb.: X (D), 498, UKRAINE, Dniepopetrovskaia, Deryiova s.n. (LE); E. sanguischristi Sennen: $X^{*}, 464$, SPAIN, Castellón, Peñíscola, Aldasoro and Alarcón (MA); E. sebaceum: $X^{*}, 846$, Morocco, Aguelmane, Devesa s.n. (SEV); E. stephanianum: $A^{*}, 195$, Cult. in MA from seeds taken in Qinghai, China, Ho et al. (MA); E. tataricum Willd.: X, 980, RUSSIA, Jakasia, Abakan, Titov s.n. (LE); E. texanum: F*, 74, USA, Texas, Post, García \& Martín (MA); E. tibetanum Edgew. in Hook. f.: A, 160, CHINA, Laddakh, Margalef Mir s.n. (BC); E. tordylioides: X*, 1124, SPAIN, Cadiz, Zahara, Aldasoro and Alarcón 5022 (MA); E. touchyanum Delile ex Godr.: A-F*, 371, MOROCCO, Taza, Jury 13801 (SEV); E. trichomaniifolium L'Hér.: X* (D), 512, TURKEY, Karaman-Ermenek, Aldasoro et al. 9119 (MA); E. trifolium (Cav.) Cav.: X*, 1335, TUNISIA, Rohnia, Aldasoro et al. 5033 (MA).

Geranium aculeolatum: X-F*, 440, TANZANIA, Kilimanjaro, Schlieben 4379 (MA); G. aequale (Bab.) Aedo: A, 146, GREAT BRITAIN, Circester, Airy Shaw s.n. (MA); G. albanum: X*, 880, GEORGIA, Kiziki, Sachokia s.n. (MA); G. albicans A. St-Hil., A-F, 160, Uruguay, Timote, Rossengutt 5290 (MA); G. arachnoideum A. St-Hil.: X-F, n, BRASIL, Itatiaia, Alves \& Marín 2762 (MA); G. arboreum A. Gray: X, 840, HAWAI, Maui, Haleakala, Stauffer and Gillett 5888 (P); G. aristatum: X, 804, MACEDONIA, Mavrovo Lake, Frost Olsen 6377 (MA); G. asphodeloides: X*,1048, TURKEY, Evciler, Kav Dagh Castroviejo 15220 (MA); G. atlanticum Boiss.: X, 710, Cult. in Reading from seeds taken in Morocco, Beni Snassen, Aedo 5431 (MA); G. austroapenninum: $X^{*}$, 976, ITALY, Abruzzo, Herrero et al. 2073 (MA); G. azorelloides: F-A, 184, COLOMBIA, Aedo et al. (2002; G. berteroanum Colla: A, 96, CHILE, Magallanes, $\mathrm{P}^{\circ}$ Natales, Aedo 7468 (MA); G. bicknellii: A*, 140, Cult. in MA, Aedo s.n. (MA); G. biuncinatum: A, 32, YEMEN, HillaAttuba, Wood 3126 (MA); G. bohemicum L.: A-F*, 216, SPAIN, Zamora, Ribadelago, Montserrat s.n. (MA); G. brasiliense: X-F, 360, BRASIL, S. Catarina, Pereira \& Pabst 6170 (MA); G. brevicaule Hook.: A-F*, 136, Cult. in MA, Aedo 4475 (MA); G. brycey: X*, 456, Cult. in MA; Aedo 4474 (MA); G. caeruleatum Schur: $X^{*}(\mathrm{GD}), 529$, Bulgaria, Mt Vitosha, Alarcón et al. 203 (MA); G. caespitosum, X-F, n,USA, Colorado, Clear Creek, Nieto Feliner 2288 (MA); G. caffrum: X, 242, Cult. in MA, Aedo 4472 (MA); G. campii H. E. Moore: A, 170, ECUADOR, Aedo et al. (2002); G. carolinianum L.: A*, 118, USA, Alabama, Flat Creek, Diamond 13019 (MA); G. cataractarum: X*, 916, SPAIN, Jaén, Nava de S Pedro, Soriano 3191 (MA); G. cinereum: X*,
1020, SPAIN, Santander, Castrovalnera, Aldasoro and Alarcón 9201 (MA); G. columbinum: A*, n, SPAIN, Castellón, Peñagolosa, Aedo \& al. sn . (MA); G. collinum Stephan ex Willd.: $X^{*}, 736$, SPAIN, Cuenca, Uña, Aldasoro and Alarcón 8627 (MA); G. core-core: A-F, 159, CHILE, Antofagasta, Aedo 7073 (MA); G. costarricense: X-F*, 428, Cult. in MA from seeds taken in Costa Rica, Chirripó, Aedo et al. (2002); G. crassipes Hook. Ex A. Gray: F, 208, PERÚ, Aedo et al. (2002); G. crenophillum Boiss.: X, 994, LEBANON, Ehden, Pabot s.n. (G); G. cuneatum subsp. hololeucum (A. Gray) Carlquist \& Bissing: X-F, 256, SANDWICH ISLANDS, Remy 628 (P); G. digitatum R. Knuth: X, 628, PERÚ, Aedo et al. (2002); G. dissectum L.: A, 112, Spain, Teruel, Valderrobles, Aedo et al. 5077 (MA); G. divaricatum Ehrh.: A,124, TURKEY, Ghumushane, Herrero et al. 1467 (MA); G. dolomiticum: X, 1078, SPAIN, Leon, Villanueva de Valdelosa, Valdés 9792 (MA); G. ecuadoriense Hieron.: F, 230, ECUADOR, Chimborazo, Guaranda, Luteyn 11074 (MA); G. endressii: $X^{*}, 1086$, Cult. in Jaca from seeds collected in E. Pirineos, France, Montserrat 922 (MA); G. erianthum DC.: X, 822, RUSSIA, Kuriles Is., Gage s.n. (MA); G. exallum H. E. Moore: F-A, 218, ECUADOR, Aedo et al. (2002); G. fallax Steud., A-F, 124, BOLIVIA, Potosi, Schulte 92 (MA); Calacoto, Beck 2401 (MA); G. favosum Steud.: F, 340, LEBANON, Sinpe, Hohenaker 1854 (MA); G. foreroi Aedo: X, F, 442, COLOMBIA, S. Nevada de Santa Marta, Pico J. Hilario, Forero 635 (MA); G. glaberrimum: X*, 902, TURKEY, Karajosan Gecidi, Aldasoro et al. 9168 (MA); G. glanduligerum R. Knuth in Engler: F, 310, BRASIL, Sao Paulo, Jordao, Texeira 337 (MA); G. gracile: X*, 669, TURKEY, Trabzon, Valcarcel 370VV01 (MA); G. gymnocaulon: X, 946, GEORGIA, Abjasia, Mts. Dzyra-Mts. Cipsira, Kolakovsky s.n. (LE); G. holosericeum Willd. ex Spreng.: X, 418, COLOMBIA, Cundinamarca, Sumapaz, Pedraza et al. 320 (MA); G. humboldtii Spreng: F, 240, ECUADOR, Volcan Antisana, La Mica, Vargas \& Narváez 2151 (MA); G. ibericum Cav.: X, 1096, GEORGIA, S Ossetia, Ermani-don, Gochina s.n. (MA); G. incanum Burm. f.: $X^{*}, 452$, SOUTH AFRICA, Cape, Kirstenboch Garden, Aldasoro et al. 9097 (MA); G. jahnii Standl.: F, 266, VENEZUELA, Páramo de Jabón, Trujillo, Riina et al. 597 (MA); G. kilimandscharicum Eng.: A, 90, TANZANIA, Kilimanjaro, unknown collector (P); G. kotschy Boiss, $X^{*}(\mathrm{GD}), \mathrm{n}$, Cult. in MA from seeds collected in Iran, Kosh-e-Yelag, Aedo 9888 (MA); G. krameri Franch. \& Sav.: $X^{*}, 618$, Cult. in MA from seeds collected by Compton in Kaybang, S Korea; Alarcón and Aldasoro s.n. (MA); G. lanuginosum Lam.: A-F*, 196, SPAIN, Barcelona, Mataró, Montserrat s.n. (MA); G. libani P. H. Davis: X, 1560, TURKEY, Iskenderun, Nydegger 45264 (G); LEBANON, Feinour, Keibrouan, Gombault 1145 (MA); G. libanoticum A. Schenk.: X, 846, LEBANON, Pabot (G); G. linearilobum DC. in Lam. \& DC.: X (GD), n, KAZAKHSTAN, Ala Tau, Levichev s.n. (MA); G. lucidum L.: A*, 69, SPAIN, Coruña, Amigo s.n. (MA); G. macbridei Aedo: X-F, 396, PERÚ, Aedo et al. (2002); G. macrorrhizum: X*, 472, CROATIA, Krasno-Jablanac, Frost Olsen 5202 (MA) and cult. in MA; G. macrostylum Boiss.: X, n, TURKEY, Lydia, Boissier 46 (P); G. maculatum L.: X* (GD), 1062, Cruden (1977); G. maderense Yeo: $X^{*}, 562$, MADEIRA IS., Bica de Cana, Aedo 9696 (MA); G. magellanicum Hook. f.: A-F, 144, CHILE, La Araucania, Volcán Llaima, Aedo 7224 (MA); G. makmelicum Aedo: X, 756, LEBANON, Cedres, Gombault 1143 (MA); G. malviflorum Boiss. \& Reut.: X, 668, SPAIN, Granada, S Nevada, Smelsson (G); G. maniculatum H. E. Moore: A, 176, ECUADOR, Aedo et al. (2002); G. mascatense Boiss, $\mathrm{F}^{*}, 288$, Cult. in MA from seeds collected in Oman, Aedo 6083 (MA); G. molle L.Geranium:molle: A*, 152, SPAIN, Salamanca Alarcón and Aldasoro s.n (MA); G. moupinense Franch.: X, 686, CHINA, Tibet, Moupin, David 1870 (MA); G. multiceps Turcz.: X, 378, VENEZUELA, Trujillo, Guirigai, Dorr 9133 (MA); G. multipartitum Benth.: A,166, ECUADOR, Aedo et al. (2002); G. nivale R. Knuth: X-F, 416, PERÚ, Aedo (2002); G. nepalense Sweet: F-X, 228, JAPAN, Hokkaido, Shireteki, Estébanez s.n. (MA); G. nodosum: X*, 702, ITALY, Abruzzo, Herrero et al. 1955 (MA); G. oreganum Howell: $X^{*}(\mathrm{GD}), 1326$, Cult in MA from seeds collected in USA, Aedo s.n. (MA); G. orientali-tibeticum R. Knuth: X, 620, CHINA, Tibet, Ta-tien-lou, Drake 553 (MA); G. ornithopodon Eckl. \& Zeyh.: X, 460, SOUTH AFRICA, Queenstown, Cooper 434, (MA); G. palmatum: $X^{*}, 700$, PORTUGAL, Madeira, Cantias, Medina 2448 (MA); G. paludosum R. Knuth, F, 280, COLOMBIA, Aedo et al. (2002); G. palustre L., $X^{*}, 816$, CHEKIA, Kost, Castroviejo et al. 15640 (MA); G. pavonianum Bricq.: A, 152, PERÚ, Aedo et al. (2002); G. peloponnesiacum Boiss : X, 1185, GREECE, Mesolongiou, Nielsen 11132 (UPA); G. phaeum: X*, 1020, BOSNIA, Jajce, Krach 3075 (MA); Bulgaria, Mt Vitosha Alarcón and Aldasoro s.n (MA); G. platypetalum, Fisch. ex C. A. Mey.: X*, 1371, TURKEY, Rize, Nisa et al. 893 (MA); G. potentilloides L'Her ex DC.: A*, 112, Cult. in MA Alarcón and Aldasoro s.n (MA); G. pratense L..: X*, 1100, SPAIN, Madrid, Montejo, Aldasoro s.n. (MA); G. pseudosibiricum J. Mayer: $X^{*}$ (GD), 568, Cult. in MA from seeds collected in Russia by Krutscherovskaya, Turyga river, Irkusk; Alarcón and Aldasoro s.n. (MA); G. psilostemon Ledeb.: X*(GD), 860,TURKEY, Rize, Nisa et al. 765 (MA); G. purpureum Vill.: A, 61, Herrera (1991); G. pyrenaicum: F-X*, 562, SPAIN, Santander, Alarcón and 
Aldasoro s.n. (MA); G. reflexum: X*, 766, ITALY, Pescara, Vado di Sole, Navarro et al. 4219 (MA); G. renardii Trautv. in Trautv.: X*, 1430, RUSSIA, N Ossetia, Busch s.n. (LE); G. retrorsum L'Her ex DC.: A, 80, HAWAI, Waimea, Hosaka 3590 (P); G. reuteri Aedo \& Muñoz-Garm.: F-A*, 362, SPAIN, Tenerife, Pico Villanos, Navarro et al. 3098 (MA); G. rhomboidale H. E. Moore: A, 164, COLOMBIA, Aedo et al. (2002): G. richardsonii Fisch. \& Trautv. : X (GD), 864, U.S.A., Colorado, Delta Co, Siplivinski 1755 (MA); G. robertianum: A*, 110, SPAIN, Santander, Aldasoro s.n. (MA); 140-230, Cruden (1977); G. ruizii Hieron.: F-A, 232, PERÚ, Aedo et al. (2002); G. sanguineum L.: F-X*, 612, SPAIN, Navarra, Petilla, Aizpuru 3865 (MA); G. santanderiense R. Knuth: X, 624, COLOMBIA, Cundinamarca Fernández 5156 (MA); G. sericeum Willd. ex Spreng.: X, F, 356, ECUADOR, Aedo et al. (2002); G. sessiliflorum Cav.: A*, 140, CHILE, Magallanes, Puerto Arenas, Aedo 7486 (MA); G. sibbaldioides Benth.: A, 150, PERÚ, Aedo et al. (2002); G. sibiricum L., X, n, JAPAN, Hokkaido, Estebanez (MA); G. sinenense R. Knuth in Eng.: $X^{*}, 494$, Cult in MA from seeds collected in China, Yunnan, Ou Kia Tsen, Aldasoro s.n. (MA); G. sintenisii Freyn: X, 996, TURKEY, Torul-Trabzon, Nisa et al. 712 (MA) ; G. skottsbergii R. Knuth: A*, 164, CHILE, Valparaiso, Papudo, Aedo 6824 (MA); G. soboliferum Kom.: A, 138, JAPAN, Hiroshima, Kagasuyama Park, Estébanez s.n. (MA); G. solanderi Carolin: A, 150, AUSTRALIA, Hume, Canning 4410 (L); G. stramineum Triana \& Planch.: A, 142, ECUADOR, Aedo et al. (2002); G. strictipes R. Knuth: F-A, 232, Cult. in Wakehurst Garden from seeds taken in Yunnan, China, Aedo 3886 (MA); G. subargenteum: X*, 1464, SPAIN, Santander, Alto Campoo, Aldasoro and Alarcón 9196 (MA); G. sylvaticum: X* (GD), 820, SPAIN, Santander, Portillo de la Lunada, Aldasoro et Alarcón 9209 (MA); G. suzukii Masam.: F*, 212, Cult. in MA, Aedo 4779 (MA); G. thunbergii Siebold ex Lindl. \& Paxton: F-A, 180, Cult. in MA, Aedo 3046 (MA); G. tovarii Aedo, A, F, 254, Perú, Aedo et al. (2002); G. transbaicalicum Serg.: X, 862, RUSSIA, Siberia, Zabalkaskaia, river Nercha, Sukachev 1153 (MA); G. tuberosum: $X^{*}(\mathrm{GD}), \mathrm{n}$, TURKEY, Erzurum, Palandoken dag, Herrero 1732 (MA); G. versicolor L.: X*, 954, ITALY, Sicilia, Nebrali, García et al. 1481 (MA); G. viscossisimum Fisch. \& C. A. Mey. in C. A. Mey.: X*, 994, USA, Montana, Mt Gallatin. Summers, 9312 (MA); G. wallichianum D. Don ex Sweet: $X^{*}, 446$, Cult. in P from seeds collected in India, Aedo 5170 (MA); G. weddellii Bricq.: X, 560, BOLIVIA, Aedo et al. (2002); G. wilfordii Maxim.: A, 148, CHINA, Tchen-keoutien, Farges s.n. (MA); G. wlassovianum Fisch. ex Link..: X, n, RUSSIA, L. Baikal, Komovalov (MA); G. yesoense: X, 1008, JAPAN, Toyama, Komado, Kagasuyama Park, Estébanez s.n. (MA); G. yeoi Aedo \& Muñoz-Garm.: F, 194, PORTUGAL, Madeira, Cantias, Aedo 6694 (MA).

Hypseocharis pimpinellifolia J. Remy: X 6048, ARGENTINA, Jujui, Volcán Jumbaya, Venturi 4952 (MA).

Monsonia angustifolia: A*, n, SOUTH AFRICA, Albert, Gerrard 1431 (W); M. attenuata Harv.: X, 1605, SOUTH AFRICA, Natal, Cooper s.n. (MA); M. brevirostrata Knuth: A-F*, 288, SOUTH AFRICA, Harrismith, Tafelroop, Krook 2220 (W); M. burkeana Planch. ex Harv.: X, 563, ZIMBABWE, Bulawayo, Heany 23 (COI); M. camdeboense: $\mathrm{X}^{*}$, n, SOUTH AFRICA, Craddock, Cooper 491 (COI); cult. in MA garden from seeds supplied by Silverhill seeds, Aldasoro s.n. (MA); M. ciliata (Moffet) Albers: X*, 7337, SOUTH AFRICA, Steinkopf-Violdrof, Aldasoro 9038 (MA); M. crassicaule: X*, n, SOUTH AFRICA, Castroviejo 14931 (MA); M. emarginata: X*, 2840, South Africa, East London, Phillipson 379 (UPS); South Africa, cult. in MA Garden from seeds supplied by Silverhill seeds, Aldasoro s.n. (MA).; M. glauca Knuth: X, 1007, BOTSWANA, Great Lasgtu, Smith 3258 (MO); M. grandifolia Knuth: X, 3835, SOUTH AFRICA, Natal, Alexandra, Rudatis 1342 (W); M. herrei (L. Bol.) Albers: X, 4150, SOUTH AFRICA, SteinkopfVioldrof, Aldasoro 9042 (MA); M. inerme (Rehm.) Albers: X*, n, Cult. in Kirstenboch Garden, Aldasoro s.n.(MA); M. lanuginosa Knuth: X, 3245, SOUTH AFRICA, Natal, Uporne Berg, Slechter 4734 (COI); M. Theritieri (Sweet) Albers: $X^{*}, 5730$, SOUTH AFRICA, Garies-Bitterfontein, Aldasoro 9078 (MA); M. longipes Knuth: X, 364, KENIA, Nairobi-Namanga, Polhill and Paulo 1012 (B) ; M. luederitziana Focke \& Schinz: X*, 1067, NAMIBIA, Grunau-Klein Karas, Aldasoro 9074 (MA); M. marlothii: X, n, NAMIBIA, Swakopmund, Khan canyon, Vargas (MA); M. mossamedense (Welw. ex Oliv.) Albers: $X^{*}, \mathrm{n}, \mathrm{ANGOLA}$, Mossamedes, Excdel and Mendonça 21775 (COI); M. multifida: $\mathrm{X}^{*}, \mathrm{n}$, cult. in MA Garden from seeds collected in Kirstenbosch Garden (MA); M. nivea: $\mathrm{A}^{*}, 128$, cult. in MA garden from seeds collected in Morocco, Taoujgalt, Alto Atlas, Staudinger s.n. (MA); $M$. parvifolia: X, n, NAMIBIA, Naroep, Schlechter s.n. (W); cult. in MA Garden from seeds provided by Silverhill Seeds (MA); M. pattersonii (DC.) Albers: $X^{*}, 4965$, SOUTH AFRICA, Aus-Witputz, Aldasoro 9054 (MA); $M$. praemorsa: X, 3900, SOUTH AFRICA, Natal, Clairmont, Wood s.n. (W); M. salmoniflora (Moffet) Albers: X*, 4601, SOUTH AFRICA, Aus-Witputz, Aldasoro 9049, 9053 (MA); M. senegalensis Guillemin \& Perrottet: A*, 193, CABO VERDE, Maio, Cardoso de Matos 6269 (MA); M. speciosa: X, 11753,
SOUTH AFRICA, Cape, Krasse s.n. (MA, P); M. trilobata Kers: X*, n, NAMIBIA, Keetmanshop, Narubis, Aldasoro s.n. (MA); M. umbellata Harvey: X, 257, NAMIBIA, Namibrand Karibib, Seydel 2947 (COI); M. vandierietiae: X, 4930, SOUTH AFRICA, cult. in Kirstenbosch Garden (MA).

Pelargonium acraeum R. A. Dyer: $X^{*}, \mathrm{n}$, SOUTH AFRICA, Steinkopf, Anenous Pass, Aldasoro 9040 (MA); P. alchemilloides (L.) L'Herit.: F-A*, 178, SOUTH AFRICA, cult. in Kirstenbosch Garden, Aldasoro 9091 (MA); P. althaeoides: X, n, SOUTH AFRICA, cult.at Stellenbosch Garden, Aldasoro s.n. (MA); P. aridum R. A. Dyer: X, n, cult. in Madrid Garden, Aedo sn. (MA-591592); P. australe: A, 108, AUSTRALIA, Rechinger (MA); P. betulinum (L.) L'Herit.: $\mathrm{X}^{*}, 718$, SOUTH AFRICA, cult. in Kirstenbosch Garden, Aldasoro 9092 (MA); P. caucalifolium Jacq.: $X^{*}$, 483, SOUTH AFRICA, Yzerfontein-Darling, Aldasoro 9025(MA); P. chamaedrifolium Jacq: $X^{*}$, n, SOUTH AFRICA, Franshoek Pass, Strey s.n. (COI); SOUTH AFRICA, cult. in Kirstenbosch Garden, Aldasoro s.n. (MA); P. cotyledonis: cult. in Kew Gardens, Aedo 3837 (MA); P. cortussifolium L'Herit.: X* , 645, SOUTH AFRICA, Pomona, Dinter s.n. (MA); P. crithmifolium J. E. Sm.: X, 1100, SOUTH AFRICA, Kipplantivier, Tambs s.n. (P); P. cucullatum (L.) L'Herit.: $\mathrm{X}^{*}, \mathrm{n}, \mathrm{SOUTH}$ AFRICA, Slankopf, Aldasoro 9096 (MA); P. denticulatum Jacq.: $X^{*}, 652$, SOUTH AFRICA, cult. in Kirstenbosch Garden, Aldasoro and Alarcón 306 (MA); P. elongatum (Cav.) Salisb.: X*, 223, SOUTH AFRICA, cult. at Stellenbosch Garden, Aldasoro s.n. (MA); P. endlicherianum Fenzl.: X*, 1232, TURKEY, Ermenek-Anamur, Aldasoro 9148 (MA); P. fulgidum (L.) L'Herit.: $X^{*}, 910$, SOUTH AFRICA, Nuwerus, Aldasoro 9035 (MA); P. glutinosum (Jacq.) L'Herit.: $X^{*}, 526$, SOUTH AFRICA, cult. at Kirstenbosch Garden, Aldasoro 9096 (MA); P. grossularioides (L.) L'Herit.: A-F, n, MOZAMBIQUE, Ilha da Inhaca, A. Reis Moura 738 (MA); P. incarnatum (L'Herit.) Moench.: X, 460, SOUTH AFRICA, Cape, Drege 1838 (P); P. inodorum Willd.: A, 228, AUSTRALIA, Rechinger (MA); P. luridum (Andr.) Sweet: X, 390, SOUTH AFRICA, Namaqualand, Reis Moura (MA); P. minimum (Cav.) Willd.: A-F*, n, SOUTH AFRICA, SW Cape, Aldasoro s.n. (MA); Paarlberg, Drege 1276 (P); P. myrrhifolium: X, 610, SOUTH AFRICA, Cape B. Esperanza, Cavanilles s.n. (MA); P. ovale (Burm.f.) L'Herit.: X, 696, SOUTH AFRICA, Barus Plaaf, Slechter 9139 (COI); P. pseudofumarioides Knuth: A-F*, 163, SOUTH AFRICA, Cape, Citrusdal, Aldasoro s.n. (MA); P. reniforme (Andr.) Curt. : X, 361, SOUTH AFRICA, Fiahamstown, Mae Owan (P); P. scabrum (Burm. f.) L'Herit.: X*, 315, SOUTH AFRICA, cult. in Kirstenbosch Garden, Aldasoro 9095 (MA); P. stipulaceum (L.f.) Willd.: X, 480, SOUTH AFRICA, Cape B. Esperanza, Cavanilles s.n. (MA); P. tetragonum (L.f.) L'Herit.: $\mathrm{X}^{*}, \mathrm{n}$, SOUTH AFRICA, cult. in Kirstenbosch Garden, Aldasoro s.n. (MA); P. triste (L.) L'Herit.: X, n, SOUTH AFRICA, Cape, Cavanilles s.n. (P); P. whytei: X, 860, MOZAMBIQUE, Mendonça s.n. (COI).

APPENDIX 3. Pollinators and visitors of Geraniaceae. We provide the following information: taxon, reference or sample data, total number of visitor taxa, visits per min (—: no data), time of observation in hours (-: unknown), visitors.

Erodium alpinum - Italy, L'Aquila, Abruzzo, Aedo et al. 8256 (MA), 10, 0.408, 4, Coleoptera: Bruchidae, Malachidae. Diptera: Syrphidae, Empididae, and Bombylidae. Hymenoptera: Anthophoridae, Cymbicidae. Lepidoptera: Lycaenidae, Satyridae, Zygaenidae. E. botrys - Spain, Salamanca, Castellanos de Moriscos, Aldasoro and Alarcón 9250 (MA), 11, 0.05, 6, Diptera: Calliphoridae; Muscidae; Pipunculidae; Syrphidae: Melanostoma sp., Syrphus ribesii. Hymenoptera: Andrenidae: Andrena sp., Anthophoridae: Anthophora sp., Chrysidae; Halictidae: Halictus sp.; Megachilidae: Coelioxis sp., Vespidae: Polistes sp. E. chium - Spain, Gerona, Cabo Norfeu, Aldasoro and Alarcón 9233 (MA), 5, 0.09, 4, Coleoptera: Oedemeridae. Diptera: Bombylidae: Bombylium maximus Syrphidae: Syrphus ribesii. Hymenoptera: Andrenidae: Andrena sp., Halictidae: Halictus sp. E. ciconium - Spain, Madrid, Aldasoro 9249 (MA); Zaragoza, Molina de Aragón Aldasoro 9245; Cuenca, Hontecillas, Aldasoro 9241 (MA); Teruel, Santa Eulalia, Aldasoro 9244 (MA), 16, 0.153, 6, Coleoptera: Oedemeridae. Diptera: Calliphoridae; Muscidae; Pipunculidae; Syrphidae: Episyrphus balteatus, Syrphus ribesii. Hymenoptera: Andrenidae ; Anthophoridae: Melecta sp.; Halictidae: Halictus sp.; Ichneumonidae; Megachilidae: Megachile sp., Macropis sp.; Osmia sp., Dasypoda sp.; Ceratina sp.; Vespidae: Polistes sp. E. cicutarium - Spain, Salamanca, Castellanos de Moriscos, Aldasoro and Alarcón 9244 (MA); Jaen, P. Almadén, Aldasoro and Alarcón, 9262; Guadalajara, Checa, Aldasoro and Alarcón, 9282, 9, 0.13, 8, Diptera: Syrphidae: Syrphus ribesii, Sphaerophoria sp. Bombylidae: Bombylius maximus ; Muscidae; Empididae. Hymenoptera: Andrenidae; Halictidae: Halictus sp.; Tenthredinidae; Torymidae. E. daucoides - Spain, Burgos, Sargentes de Lora, Aldasoro and Alarcón 8831, 9265 (MA); Guadalajara, Pálmaces de Jadraque, Aldasoro and Alarcón 8834 (MA); Granada, Mt. Cañadillas Alda- 
soro and Alarcón 9217 (MA), 11, 0.11, 6, Diptera: Syrphidae: Episyrphus balteatus, Sphaerophoria sp., Syrphus ribesii, Bombylidae: Bombylius maximus. Hymenoptera: Andrenidae : Andrena sp.; Cymbicidae; Formicidae; Halictidae: Halictus sp.,Lassioglosum sp.; Apidae : Apis mellifera; Vespidae : Eumenes sp. E. foetidum - Spain, Teruel, Javalambre, Aldasoro and Alarcón 9213, 9263 (MA) Teruel, Puerto de Cabigordo, Aldasoro and Alarcón 9213, 9243 (MA), Murcia, Sierra de Espuña, Aldasoro and Alarcón 9210, 9231, 9274 (MA); Jaen, Pico Almadén Aldasoro and Alarcón 9220, 9259; Gerona, Cabo Norfeu, Aldasoro and Alarcón 9253, 9224 (MA), 17, 0.178, 36, Coleoptera: Oedemeridae. Diptera: Bombylidae: Bombylius sp., Empididae, Muscidae, Phoridae, Tachinidae, Syrphidae: Syrphus ribesii, Volucella sp., Scaeva albomaculata, Sphaerophoria scripta. Hymenoptera: Andrenidae: Andrena, Anthophoridae, Formicidae, Halictidae: Halictus, Ichneumonidae, Platigasteridae, Sphecidae. E. glandulosum - Spain, Palencia, Valdecebollas, Aldasoro and Alarcón 8832 (MA); Teruel, Puerto del Portillo, Aldasoro and Alarcón 8828 (MA), 8, 0.12, 12, Diptera: Syrphidae: Syrphus ribesii, Scaeva sp. Hymenoptera: Cymbicidae, Andrenidae: Andrena sp., Halictidae: Halictus sp, Lassioglossum sp., Sphecidae. E. glandulosum - Simon et al. (2000), Palencia, Valdecebollas, Aldasoro and Alarcón 8832 (MA); Teruel, Puerto del Portillo, Aldasoro and Alarcón 8828 (MA), 10, -, 一, Coleoptera: Oedemeridae: Oedemera sp.; Chrysomelidae: Clytra sp.; Curculionidae: Miarus sp.. Diptera: Syrphidae: Syrphus ribesii, Scaeva sp., Paragus sp. Heteroptera: Miridae: Amirida sp. Hymenoptera: Formicidae: Formica sp., Halictidae: Lassioglossum sp, Sphecidae: Stigmus sp. E. glaucophyllum Tunisia, Moulares, Aldasoro 3043 (MA); between Tataouine and Chenini, Bernardos s.n. (SALA); Ghomrassen, Bernardos s.n. (SALA); between Mededine and Matmata, after Matameurtra, Bernardos s.n. (SALA); between Matmata and Douz, km 76, Bernardos s.n. (SALA); between Djebel Tamezret and Hachichina near Chott El Fejaj, Bernardos s.n. (SALA), 12, 0.124, 6, Coleoptera: Chrysomelidae: Lachnaia sp., Anobiidae. Diptera: Asilidae: Asilus sp., Scathophagidae, Anthomiidae. Hymenoptera: Andrenidae: Andrena sp., Chrysidae: Chrysis sp., Halictidae: Halictus sp., Lasioglosum sp., Doufurea sp.; Ichneumonidae: Ryssa sp., Melittidae: Melitta sp. E. macrocalyx - Spain, Cuenca, Tragacete, Aldasoro and Alarcón 8825, 9216 (MA); Cuenca, Masegosa, Aldasoro and Alarcón 8824, 9214 (MA), 8, 0.08, 4, Diptera: Syrphidae : Scaeva sp., Muscidae. Hymenoptera: Andrenidae: Andrena sp. ; Halictidae: Halictus sp., Lasioglosum sp., Sphecidae. Lepidoptera: Lycaenidae. E. malacoides - Spain, Salamanca, Aldasoro and Alarcón 3472 (MA); Cuenca, Hontecillas, Aldasoro and Alarcón 9255, 9240 (MA); Murcia, Sierra de Espuña, Aldasoro and Alarcón 9233 (MA), 9, 0.142, 6, Coleoptera: Buprestidae. Diptera: Bombylidae: Bombylius maximus, Syrphidae: Syrphus ribesii, Episirphus balteatus. Hymenoptera: Andrenidae: Andrena sp., Anthophoridae, Halictidae: Halictus sp., Megachilidae Ceratina sp. E. paularense - Spain, Madrid, El Paular, Aldasoro and Alarcón 9239 (MA); Guadalajara, Cañamares, Aldasoro and Alarcón 8835, 9246 (MA), 15, 0.194, 7, Coleoptera: Mordellidae, Dermestidae. Diptera: Empididae; Platypecidae, Calliphoridae, Muscidae; Syrphidae Syrphus ribesii. Hymenoptera: Anthophoridae: Anthophora sp., Eucera sp., Apidae: Apis mellifera. Halictidae: Halictus, Megachilidae: Megachile sp., Formicidae. Satyridae: Coenonympha sp. Neuroptera. E. pelargoniflorum - Turkey, between Ermenek and Anamur, Aldasoro et al. 9150 (MA), 9, 0.2, 3, Coleoptera: Dasytidae. Diptera: Syrphidae, Bombylidae: Bombylius sp., and Muscidae. Hymenoptera: Anthophoridae: Anthophora sp., Apidae: Psithyus sp., Sphecidae, Sapygidae. Lepidoptera: Lycaenidae: Lyssandra $\mathrm{sp}$.

Geranium arboreum - Medeiros and St John (1988): 1, —, -, Birds: Fringillidae. G. austroapenninum - Italy, Abruzzo, Herrero et al. 2073 (MA), 10, 0.383, 4, Coleoptera: Malachidae, Bostrychidae, Curculionidae, Meloideae, Oedemeridae. Diptera: Muscidae and Empididae. Hymenoptera: Apidae: Apis mellifera, Cymbicidae, Formicidae. G. brevicaule- Philipp (1985): 4, - , 8-32, Coleoptera. Hemiptera. Formicidae. Lepidoptera: Lycaenidae. G. caespitosum - Goertz (2004): 11, _, - Hymenoptera: Andrenidae: Andrena; Hoplitis albifrons, Macropis, Megachilidae: Megachile mendica. G. caespitosum - Hessing (1989): -, - , 6, Hymenoptera: Halictidae, Collettidae, Anthophoridae, Andrenidae, Apidae: Apis mellifera, and Bombus spp. G. caespitosum - Pleasants (1980): -, -, 3-12, Hymenoptera: Apidae: Apis mellifera, Bombus flavifrons, B. bifarius, Diptera. G. cinereum - Spain, Santander, Castrovalnera, Aldasoro and Alarcón 9201 (MA), 4, 0.167, 4, Diptera: Muscidae. Hymenoptera: Anthophoridae, Apidae: Apis mellifera, Halictidae: Halictus sp. G. collinum - Spain, Cuenca, Uña, Aldasoro and Alarcón 8627 (MA): 7, 0.189, 5, Coleoptera: Chrisomelidae. Diptera: Syrphidae, Conopidae. Hymenoptera: Andrenidae: Andrena sp., Apidae: Apis mellifera and Halictidae: Halictus. Heteroptera: Pentatomidae. G. maculatum Willson et al. (1979): 3, —, —, Hymenoptera: Andrenidae: Andrena sp., Apidae: Apis mellifera, Bombus sp. G. molle Spain, Salamanca, Castellanos de Moriscos, Aldasoro and Alarcón, 9235,
9248 (MA), 6, 0.233, 6, Syrphidae: Sphaerophoria sp., Leucozona sp.; Empididae; Scathophagidae. Hymenoptera: Andrenidae: Andrena sp.; Halictidae: Halictus sp. G. palustre - Dlussky et al. (2000): 16, -, -, Diptera: Syrphidae: Sphaerophoria sp., Helophilus pendulus, Epysyrphus balteatus, Syritta pipiens, Episyrphus balteatus; Empididae: Empis livida.; Muscidae: Phaonia basalis, Antomydae: Phorbia sp., Calliphoridae: Melinda biseta. Hymenoptera: Megachilidae: Chelostoma sp., Apidae: Bombus sp., Halictidae, Andrenidae: Macropis fulvipes. Lepidoptera: Hesperidae: Hesperis comma, Pieridae: Pieris napi. G. phaeum - Bulgaria, Mt Vitosha, Aldasoro and Alarcón 8821 (MA): 5, 0.083, 4, Diptera: Calliphoridae; Syrphidae: Syrphus ribesii; Melanostoma sp. Hymenoptera: Megachilidae: Chelostoma sp; Halictidae: Halictus calcaetum. G. pratense - Proctor et al. (1996): 2, 一, 一, Hymenoptera: Halictidae: Halictus, Apidae: Apis mellifera. G. pratense Dlussky et al. (2000): 2, -, -, Hymenoptera: Apidae: Apis mellifera, Bombus sp. G. pratense - Spain, Cult in MA, Aldasoro 9887 (MA): 6, 0.08, 4, Apidae: Apis mellifera; Scolidae: Scolia sp., Apidae: Apis mellifera, Bombus sp.; Collettidae; Megachilidae: Anthidium sp., Coelioxys inermis. G. pyrenaicum - Spain, Santander, Alarcón and Aldasoro 9261 (MA): 5, 0.133, 5, Diptera: Syrphidae : Episyrphus balteatus; Rhyngia campestris. Megachilidae, Halictidae : Halictus sp. ; Colletidae. G. reinii - Yumoto (1986): 3, —, 70, Syrphidae: Chrysotoxum sp. Hymenoptera: Apidae: Bombus beaticola, B. hypocrita. G. richardsonii - Green (1978): 9, 0.012, 56, Coleoptera: Trichiotinus assimilis, Mordella atrata, Trichodes ornatus, Epicauta puncticollis. Hymenoptera: Halictidae: Dialictus sp.; Apidae: Bombus rufocinctus, B. bifarius, Apis melifera. Lepidoptera. G. robertianum - Tofts (2004): 35, 一, -, Coleoptera: Meliridae; Byturidae; Curculionidae: Limobius borealis; Zacladius exiguous; Staphilinidae: Anthobium sp. Diptera: Cecidomiiidae, Syrphidae: Rhingia campestris, R. rostrata, Epysyrphus balteatus, Syritta pipiens, Syrphus ribesii; Empididae: Empis sp.; Agromyzidae: Agromyza nigrescens; Muscidae. Hemiptera. Hymenoptera: Megachilidae: Anthidium manicatum, Stelis phaeoptera, Chelostoma campanularum, C. nigricorn, Coelioyis sp.; Osmia sp. Halictidae: Halictus calcaetum, Andrenidae: Andrena bicolour; Apidae: Apis mellifera; Bombus sp. Lepidoptera: Pieridae: Anthocharis cardamines, Leptidea sinapis, Pieris napi, P. rapae; Pterophoridae: Amblyptilia punctidactyla, A. acanthidactyla. G. robertianum - Spain, Santander, Aldasoro and Alarcón 9201 (MA): Syrphus ribesii; Sphaerophoria sp., Rhingia campestris; Empididae: Empis sp.; Muscidae. Andrenidae: Andrena; Halictidae: Halictus sp., Megachilidae: Chelostoma sp. G. sanguineum - Philipp and Hansen (2000): 1, - , 5, Apidae: Bombus sp. G. sanquineum - Spain, Madrid, El Escorial, Aldasoro s.n. (MA), Diptera: Conopidae; Syrphidae. Hymenoptera: Vespidae: Polistes, Eumenes, Megachilidae, Collettidae, Halictidae, Andrenidae. G. subargenteum - Spain, Santander, Alto Campoo, Aldasoro and Alarcón 9196 (MA), 7, 0.211, 6, Diptera: Syrphidae. Hymenoptera: Andrenidae, Apidae: Apis mellifera, Bombus pratorum; Halictidae: Halictus sp., Colletidae, Megachilidae. G. sylvaticum - Totland (1993): 7, 0.059, 35-40, Diptera: Muscidae: Thricops aculeipes, T. nigritellus; Syrphidae: Platycheirus manicatus; Dolichopodidae: Dolichopus plumipes Anthomyiidae: Pegoplata aestiva. Hymenoptera: Apidae: Bombus lapponicus. Lepidoptera: Lycaenidae: Albulina orbitulus. G. thunbergii - Kandori (2002): 27, 0.209, 30, Diptera: Syrphidae: Betasyrphus serarius, Sphaerophoria macrogaster, Episyrphus balteatus, Metasyrphus ferquens, Paragus haemorrhous; Calliphoridae: Stomorhina obsoleta; Phasiidae: Gymnosoma rotundata. Hymenoptera: Apidae: Bombus diversus, Apis cerana. Colletidae: Hylaeus sp. Formicidae; Halictidae: Lasioglossum scitulum, Lasioglossum sp. Megachilidae: Coelioxys fenestrata, C. yanonis, C. acuminata, Megachile tsurugensis, M. remota, Chalicodoma spissula, Ceratina izwatai, Ceratina sp., Vespidae: Polistes chinensis, Eumenidae: Eumenes samuray. Lepidoptera: Pieridae: Pieris rapae, Zizeeria maha, Lampides boeticus, Parnara guttata, Cephonodes hylas. G. viscossisimum - Green (1978): 9, - , 56, Coleoptera: Trichodes ornatus, Epicauta puncticollis, Mordella atrata. Hymenoptera: Halictidae: Dialictus; Anthophoridae: Anthophora terminalis; Apidae: Apis mellifera, Bombus rufocinctus, B. bifarius, B. occidentales. G. yesoense - Nakano and Washitani (2003): 7, - , 70, Diptera: Syrphidae. Hymenoptera: Halictidae, Andrenidae, Megachilidae, Apidae: Bombus sp. Coleoptera.

Monsonia ciliata - South Africa, Steinkopf-Violdrof, Aldasoro 9038 (MA); $20 \mathrm{~km}$ to Nuwerus, Aldasoro 9035 (MA), 9, 0.275, 6, Diptera: Bombylidae: Exoprosopa sp. Hymenoptera: Anthophoridae: Amegilla sp., Collettidae: Hylaeus sp.; Megachilidae: Hoplitis sp.; Vespidae : Masarinae: Celonites, Formicidae: Myrmicaria sp., Crematogaster sp. Lepidoptera: Lycaenidae, Gelechidae : Gelechia sp. M. drudeana - Namibia, Garoeb, Aldasoro 9065 (MA); $1.5 \mathrm{Km}$ of Garoeb Aldasoro 9068 (MA), 2, 0.005, 6, Hymenoptera: Formicidae: Messor capensis. Lepidoptera: Gelechidae: Gelechia sp. M. Theritieri - South Africa, Springbock, Aldasoro 9036 (MA); GariesBitterfontein, Aldasoro 9078 (MA), 3, 0.033, 4, Diptera: Bombylidae: Exoprosopa sp.; Muscidae. Hymenoptera: Anthophoridae: Amegilla sp. M. salmoniflora - South Africa, Aus-Wiputz, Aldasoro 9049 (MA); 55 Km of 
Aus, Aldasoro 9054 (MA); S of Aus, Aldasoro 9055 (MA), 2, 0.017, 4, Hymenoptera: Halictidae, Anthophoridae: Amegilla sp.

Pelargonium alchemilloides - Vogel (1954): 1, —, -, Diptera: Tabanidae: Philoliche rostrata. P. alternans - Struck (1997): 1, - , 4-15, Hymenoptera: Anthophoridae: Amegilla niveata. P. antidysenthericum - Scheltema and Van der Walt (1990): 1, 一, -, Diptera: Bombylidae. P. appendiculatum Manning and Goldblatt (1997): 1, —, —, Diptera: Nemestrinidae: Moegistorhynchus longirrostris. P. articulatum - Struck (1997): 1, - , 4-15, Diptera: Tabanidae: Philoliche rostrata. P. barkly - Struck (1997): 1, -, 4-15, Diptera: Tabanidae: Philoliche rostrata. P. betulinum - Struck (1997): 1, -, 4-15, Diptera: Tabanidae: Philoliche lateralis. P. burgerianum - Struck (1997): 1, -, 4-15, Diptera: Bombylidae: Megapalpus capensis. P. candicans - Struck (1997): 3, _, 4-15, Hymenoptera: Anthophoridae: Amegilla spilostoma; Apidae: Apis mellifera. Coleoptera: Scarabeidae. P. capitatum - Struck (1997): 5, - , 4-15, Diptera: Tabanidae: Philoliche lateralis; Nemestrinidae: Prosoeca sp. Hymenoptera: Megachilidae: Hoplitis; Vespidae: Celonites bergewhaliae, C. wahlembergiae. P. carneum - Manning and Goldblatt (1995); Johnson in Struck (1997): 2, —, -, Lepidoptera: Nymphalidae: Princeps sp. P. coronopifolium - Albers pers. comm. in Struck (1997): 1, 一, 一, Hymenoptera: Apidae: Apis mellifera. P. cortussifolium - Manning and Goldblatt (1995, 1996): 2, 一, -, Diptera: Nemestrinidae: Prosoeca peringueyi. P. crassicaule - Manning and Goldblatt $(1995,1996)$ : 1, —, 4-20, Diptera: Nemestrinidae: Prosoeca peringueyi. P. crispum - Struck (1997): 1, 4-15, Hymenoptera: Anthophoridae: Anthophora. P. crithmifolium - Struck (1997): 2, - , 4-15, Hymenoptera: Anthophoridae: Amegilla niveata, A. obscuriceps. P. cucullatum - Marloth (1908): 1, - , 4-15, Diptera: Tabanidae: Philoliche rostrata. P. denticulatum - Van der Walt et al. (1990): 1, -, 一, Diptera: Tabanidae: Philoliche gulosa. P. dipetalum - Manning and Goldblatt (1995): 1, —, - Diptera: Nemestrinidae: Prosoeca longipennis. P. dolomiticum - Zietsman (1993): 1, 2.2, 8, Hymenoptera: Apidae: Apis mellifera. P. echinatum - Struck (1997): 1, - 4-15, Diptera: Nemestrinidae: Prosoeca peringueyi. P. elongatum - Manning and Goldblatt (1995): 1, 一, -, Diptera: Philoliche rostrata. P. endlicherianum - Turkey, Ermenek-Anamur, Aldasoro 9148 (MA): 1, - 4, Lepidoptera: Satyridae: Neohipparchia statilinus. P. flabellifolium - Maggs pers. comm. in Struck (1997): 1, —, -, Birds: Passeriformes, Nectariniidae: Nectarinia famosa. P. flabellifolium - Albers pers. comm. in Struck (1997): 1, —, -, Birds: Passeriformes, Nectariniidae: Nectarinia chalybea. P. fruticosum - Struck (1997): 5, - , 4-15, Hymenoptera: Apidae: Apis mellifera. Diptera: Tabanidae: Philoliche formosa, P. gulosa. Lepidoptera: Nymphalidae: Tarsocerus cassus; Lycaenidae. P. glutinosum Struck (1997): 2, - , 4-15, Hymenoptera: Apidae: Apis mellifera. P. glutinosum - South Africa, cult. at Kirstenbosch Garden, Aldasoro 9096 (MA):
—, - , 4, Hymenoptera: Lepidoptera: Lycaenidae. P. grossularioides Struck (1997): 1, - 4-15, Hymenoptera: Apidae: Apis mellifera. P. heterophyllum - Struck (1997): 1, —, -, Diptera: Bombylidae: Megapalpus capensis. P. incrassatum - Manning and Goldblatt (1996), Goldblatt et al. (1995), Steiner pers. comm. in Struck (1997): 1, - , 4-20, Diptera: Nemestrinidae: Prosoeca peringueyi. P. klinghardtense - Gess and Gess (2006): 2, —, - , Hymenoptera: Vespidae: Masarinidae: Jugurtia sp., Masarina sp. P. laevigatum - Struck (1997): 2, - , 4-15, Diptera: Tabanidae: Philoliche formosa, P. gulosa. P. longicaule - Goldblatt et al. (1995); Manning and Goldblatt (1997): 1, - , 4-20, Diptera: Nemestrinidae: Moegistorhynchus longirrostris. P. longiflorum - Struck (1997): 1, - 4-15, Diptera: Bombylidae: Anastoechus phaleratus. P. luteolum - Struck (1997): 2, -, 4-15, Diptera: Bombylidae: Lithorina macropterus. P. luteolum - South Africa, Darling, Aldasoro et al. 9027 (MA): 1, —, 4-15, Diptera: Bombylidae: Bombomya discoidea. P. magenteum - Manning and Goldblatt (1995, 1996): 1, —, 4-20, Diptera: Nemestrinidae: Prosoeca peringueyi. P. minimum - Vogel (1954): 1, —, - , Hymenoptera: Formicidae. P. myrrhifolium - Struck (1997): 2, —, 4-15, Diptera: Bombylidae. Hymenoptera: Megachilidae. P. ocellatum Van der Walt et al. (1990): 4, - 3, Diptera: Bombylidae: Megapalpus capensis, Lithorina sp.; Tabanidae: Philoliche angulata. Hymenoptera: Apidae. P. papilionaceum - Albers pers. comm. in Struck (1997): 1, —, 一, Hymenoptera: Apidae: Apis mellifera. P. peltatum - Struck (1997): 3, 一, 4-15, Coleoptera: Scaraboidea: Peritrichia capicola. Diptera: Tabanidae: Philoliche formosa, P. gulosa. P. pilosellifolium - Struck (1997): 1, —, 4-15, Hymenoptera: Anthophoridae: Amegilla spilostoma. P. pinnatum - Manning and Goldblatt $(1995,1996) 1, \ldots, \ldots$, Diptera: Nemestrinidae: Prosoeca longipennis. P. praemorsum - Struck (1997): 2, - , 4-15, Diptera: Bombylidae: Parisus eurhynatus, Systoechus scabrirrostris. P. rapaceum - Struck (1997): 2, - , 4-15, Hymenoptera: Anthophoridae: Amegilla atrocincta, A. spilostoma. P. scabrum - Struck (1997): 5, - , 4-15, Diptera: Bombylidae, Nemestrinidae. Hymenoptera: Apidae: Apis mellifera, Anthophoridae: Amegilla niveata. Lepidoptera: Lycaenidae: Cacyreus marshalli. P. scabrum South Africa, cult. at Kirstenbosch Garden, Aldasoro 9095 (MA): 2, —, 3, Hymenoptera: Anthophoridae. Lepidoptera: Papilionidae: Papilio demodocus. P. sericifolium - Goldblatt et al. (1995), Manning and Goldblatt (1995) 1, - , 4-20, Diptera: Nemestrinidae: Nemestrinidae: Prosoeca peringueyi. P. spinosum - Struck and Van der Walt (1996): 2, -, -, Hymenoptera: Anthophoridae: Amegilla nivetata, A. diversipes. P. tricolorMcDonald and Van der Walt (1992): 3, _, , Diptera: Bombylidae: Megapalpus capensis; Calliphoridae: Cosmina fuscipennis, Rhyncomya maculata. P. trifoliatum - Struck (1997), 1, _, -, Diptera: Bombylidae: Megapalpus capensis. 